\title{
Perspective in German and French: Divergences in Formal Marking and Temporal Anchoring
}

\author{
Martin Becker $\cdot$ Jakob Egetenmeyer $\cdot$ Stefan Hinterwimmer
}

Accepted: 23 March 2021 / Published online: 26 April 2021

(C) The Author(s) 2021

\begin{abstract}
In narratives, either a narrator or a protagonist may be the perspective taker. Importantly, shifts between the two are possible. German and French differ with respect to the means which indicate that the perspective is shifted. While German may use a specific pronoun to indicate that the perspective is shifted from the protagonist to the narrator, French may display tense-aspect forms deviating from the expected ones. In our analysis, we take into account larger strings of context, thus committing to the discourse level. We apply a staged translation approach. This allows us to determine more precisely the diverging functioning of the languagespecific means of perspective marking. The comparison of the means indicating perspective shifts opens a second question. If French allows for deviating tenseaspect forms, may the temporal anchoring diverge between the two languages? We confirm this on the grounds of a comparison of translations of German free indirect discourse to French.
\end{abstract}

Keywords Perspective Taking · Free Indirect Discourse - Determiner · TenseAspect · Language Comparison · German · French · Temporal Anchoring · Prominence

\footnotetext{
M. Becker

Romanisches Seminar, Universität zu Köln, Cologne, Germany

J. Egetenmeyer $(\bowtie)$

SFB 1252 / Romanisches Seminar, Universität zu Köln, Cologne, Germany

E-Mail: j.egetenmeyer@uni-koeln.de

S. Hinterwimmer

Bergische Universität Wuppertal, Wuppertal, Germany

SFB 1252, Universität zu Köln, Cologne, Germany
} 


\section{Perspektive im Deutschen und Französischen: Unterschiede der formalen Markierung und der zeitlichen Verankerung}

Zusammenfassung Narrative Texte folgen entweder der Perspektive eines Erzählers oder eines Protagonisten. Innerhalb eines Textes sind Perspektivwechsel möglich. Deutsch und Französisch zeigen solche Wechsel formal unterschiedlich an. Im Deutschen kann ein bestimmtes Pronomen den Perspektivwechsel vom Protagonisten zum Erzähler markieren, im Französischen können Tempus-Aspekt-Formen auftreten, die von den zu erwartenden abweichen. Unsere Analyse verpflichtet sich der Ebene des Diskurses und konzentriert sich auf längere Textsegmente. Wir wenden einen gestuften Übersetzungsvergleich an, der uns eine genauere Bestimmung der Funktionsweisen der divergierenden Mittel erlaubt. Der Vergleich eröffnet eine zweite Fragestellung. Wenn das Französische abweichende Tempus-Aspekt-Formen erlaubt, kann dann auch die zeitliche Verankerung in den beiden Sprachen voneinander abweichen? Wir bestätigen dies auf der Grundlage eines Übersetzungsvergleichs von freier indirekter Rede.

Schlüsselwörter Perspektive · Perspektivwechsel · Freie indirekte Rede · Determinierer · Tempus und Aspekt · Sprachvergleich · Deutsch · Französisch · Zeitliche Verankerung · Prominenz

\section{Introduction}

The present article studies the different strategies German and French display in marking perspective taking and viewpoint shift in discourse. Taking these phenomena as tertium comparationis of language comparison allows us to pinpoint the role of structural morpho-syntactic differences of the respective language systems in realizing discourse-specific functions such as perspective marking and - linked to it discourse structuring.

The starting point of the analysis is the observation that German and Romance languages display important differences when it comes to the role of determiners, on the one hand, and tense-aspect categories on the other, which diverge in complexity of the underlying sub-systems in the respective languages. Simply put, German has more NP forms at its disposal. In addition to personal pronouns of the er/sieles series, there are two series of demonstrative pronouns: the der/die/das series and the dieser/dieseldieses series, where the former is used more often in colloquial style, while the latter is confined to the formal register. The Romance languages (e.g., French, Spanish, Italian), in contrast, have past tenses that are also marked for aspect ([+perfective] and [+imperfective]), a differentiation that is, by contrast, not available in German. The relevance of these structural differences manifests itself in certain discourse structural configurations where an exceptional realization of a German demonstrative is paralleled by a special usage of the French tenseaspect system. The configurations we refer to are certain cases of viewpoint shift, namely, the shift from a text-internal to an external perspective. Thus, in a first step, we take perspective shift as a tertium comparationis and compare German and 
French in their strategies of marking it. We hypothesize that the differing expressive means to such an end in the two language systems are put into use in a parallel fashion, even though these means are clearly different. This is exemplified in the text passage in (1). It consists of three successive sentences, but we indicate the respective translations after each sentence. More specifically, the first enumerated lines (we use square brackets for sentence enumerations) show the Austrian-German original of one of the texts we analyze, the second lines show the French translation, which we compare it with, and the third lines add an English translation.

(1) [1] Da ist der Brenner wieder der Richtige gewesen.

Dans l'affaire de Zell, Brenner fut vraiment l'homme de la situation.

$>$ So, once again, Brenner was the right one.<

[2] Wenn man den so gesehen hat in Zell, wäre man nicht leicht darauf gekommen, dass der ein Privatdetektiv war.

À le voir comme ça, à Zell, bien malin qui aurait pu dire qu'il était détective. >If you'd seen him looking the way he did in Zell, you wouldn't have guessed that he was a private detective.<

[3] Obwohl- der war kein Geheimdetektiv. (Haas 2015, p. 15; also quoted in Hinterwimmer 2018, p. 132)

De toute façon, l'enquête n'avait rien de confidentiel. (Reygnier 2007, p. 20 f.) >Even though he was no undercover detective.<(Janusch 2014, p. 14)

In the German original, the d-pronouns den ( $>$ him $<$ ) and der (>he $<$ ) (sentences [2] and [3] $)^{1}$ mark a shift to the narrator perspective, while in the French translation the perfective tense-aspect form fut ( $>$ was $<$ ) formally marks the shift by means of a deviation from the expected imperfective form était (>was $<$ ). The example is discussed in more detail in Section 7.

In a second step, we concentrate on free indirect discourse (see Section 2 for examples) and show that the difference in resources concerning tense-aspect forms also has effects on the availability of certain temporal configurations. More specifically, the two languages differ in the flexibility of perspective time.

The present article is a contribution to the study of formal means associated with perspective taking and viewpoint shift, as well as the setting of perspective time. Methodologically, our contribution inscribes itself in the perspective of discourse analysis, dwelling on a translational approach. This approach is prone to highlighting systematic differences between the two languages under scrutiny by showing how the same conceptual content is linguistically elaborated in different manners.

The analysis consists of two parts. To make sure our sample contains sufficient instances of the phenomena under investigation, we use two different data sets.

(i) For the diverging indications of perspective shift, we analyze two detective novels by Wolf Haas about the private investigator Brenner. The style used in the original Austrian German is firmly marked. It has a tendency towards the spoken variety. This makes it especially interesting. The described properties enable the

\footnotetext{
1 We are not so much interested in the article occurring as part of the full NP der Brenner (>the Brenner $<$ ). In this case, it may be considered a colloquial feature. It is not an especially rare phenomenon. For instance, in Spanish, we also find proper names with an article (cf. De Mello 1992).
} 
author to use NPs in a particular way. For instance, in full NPs for person names, he often uses the definite article (der Brenner, >the Brenner $<$ ). More importantly, he makes use of demonstrative pronouns of the der / die / das series, even though written language typically shows a strong tendency to avoid these pronouns. The cases where the possibility is available have been analyzed in a fine-grained manner in Hinterwimmer (2018), who shows that it is precisely these cases where a shift in perspective occurs. ${ }^{2}$ Importantly however, the kind of perspective shift is not the one that is most frequently discussed in the research literature, namely that from the narrator to a protagonist. Rather, we are dealing with a shift from a text-internal character towards the narrator. We compare these properties with those contained in the French translations. Interestingly, the French counterparts do not fully maintain the marked style. This leads us to the question of how the shift in perspective is otherwise indicated, apart from more obvious lexical means. According to Sthioul (2000, p. 84, 82), the use of an unexpected tense leads to a perspectivized interpretation. We add further insight concerning tense choice in perspectivized context from Hinterwimmer (2018) and Becker/Egetenmeyer (2018). This leads us to a diversified account of tense choice in cases of perspective shift. ${ }^{3}$

(ii) Concerning the comparison of the more or less flexible perspective time in free indirect discourse (FID; for the phenomenon cf., e.g., Banfield 1982), we discuss data from two classical German novels and their translations. One is Thomas Mann's (1901) Buddenbrooks. Verfall einer Familie (>Buddenbrooks. The decline of a family<). The other one is Heinrich Mann's (1918) Der Untertan ( $>$ The patrioteer $<$ ). The novels present an elevated language containing interesting cases of FID.

We proceed as follows. In the first part, we introduce the theoretical ingredients on which our account is built and discuss the relevant phenomena in the two languages, first for German, then for Romance and especially French. More specifically, in Section 2, we describe the phenomena of perspective taking and FID following Hinterwimmer (2017). In Section 3, we add how German demonstrative pronouns can mark perspective in the vein of Hinterwimmer (2018). In Section 4, we focus on the temporal properties of discourse and introduce the three levels which constitute temporal discourse structure according to Becker/Egetenmeyer (2018). Section 5 introduces the basics of the French tense-aspect system and the approach to tense advocated by Sthioul (2000). In the second part, we present our translation account for perspective taking and the analysis. Section 6 is dedicated to our staged account of translating perspective marking from German to French. Section 7 presents our comparative analysis of the data, namely of Wolf Haas concerning viewpoint shift. The deviating use of tense-aspect forms to mark perspective shifts in French leads

\footnotetext{
2 However, as we will see, the use is not obligatory in such cases (cf. Hinterwimmer 2018, p. 130).

3 As indicated, the correlation is not trivial. We compare two formally diverging properties of two different systems. In German, this concerns the means of individual reference while in French, we focus on tenseaspect forms. The interesting parallel is that the different means fulfill parallel functions despite their differences. Finally, we also have to keep in mind that the parallels come about in deviating positions of the respective linguistic diasystem (cf. Koch/Oesterreicher 2011). While in German we deal with a diatopically and diaphasically marked variety, the French translation is comparatively close to the standard variety. It is important to note that despite this deviant categorization, we will mostly use the (overgeneralizing) terms German and French throughout the paper.
} 
us to the question of whether the variability in the choice of tense-aspect has implications for temporal anchoring. This is discussed specifically in Section 8 on the grounds of FID data in the German originals of Thomas Mann and Heinrich Mann as compared to their French translations. We conclude the article in Section 9 and briefly address open questions.

\section{Free indirect discourse, perspective taking and viewpoint shifting}

Free indirect discourse (FID) is a form of speech and thought representation which diverges decisively from both direct and indirect discourse. Most importantly, FID does not contain any direct indication that the respective sentence or text segment is to be understood as the thought or the utterance of a protagonist. The phenomenon has been puzzling narratologists and linguists for several decades and has consequently been extensively studied from a narratological (Hamburger 1968; Cohn 1978; Stanzel 1979; Banfield 1982; Fludernik 1993, 1996) as well as from a linguistic perspective (Harweg 1972; Rauh 1978; Plank 1986; von Roncador 1988; Doron 1991; Fabricius-Hansen 2002; Schlenker 2004; Sharvit 2008; Eckardt 2014; Maier 2015, 2017; Dirscherl/Pafel 2015). Before going into the details of the description of FID, consider the text segments in $(2 \mathrm{a}-\mathrm{c})$. Example $(2 \mathrm{c})$ is taken from a literary text, while (2a) and (2b) show modified versions. In each case, the second sentence is a rendition of a thought of Doris (in fact, it is always the same thought). But while in (2a) and (2b) this is explicitly signaled by the presence of the propositional attitude verb dachte (>thought $<$ ) whose subject referent is Doris, the reader needs to accommodate a corresponding thinking eventuality whose experiencer is Doris in order to arrive at a coherent interpretation in the case of $(2 \mathrm{c})$.

(2) (a) Doris seufzte. Sie dachte: »Morgen ist also der große Tag, morgen lernen wir alle den neuen Schullehrer kennen."

>Doris sighed. She thought: >So tomorrow is the big day, tomorrow we will all get to know the new school teacher.«

(2) (b) Doris seufzte. Sie dachte, dass am nächsten Tag der große Tag war, am nächsten Tag würden sie alle den neuen Schullehrer kennenlernen.

$>$ Doris sighed. She thought that the next day was the big day, the next day they would all get to know the new school teacher.<

(2) (c) [Doris] seufzte. Morgen war also der große Tag, morgen würden sie alle den neuen Schullehrer kennenlernen. (Friebel 2018, chapter 6.)

>Doris sighed. Tomorrow was the big day, tomorrow they would all get to know the new school teacher.<

Crucially, the second sentence in (2c) contains two temporal specifications that would be contradictory if they were interpreted with respect to a single context: On the one hand, the past tense marking of the finite (auxiliary) verb locates the situation introduced by the sentence prior to the temporal parameter of the context. On the other hand, the deictic temporal adverb morgen (>tomorrow $<$ ) locates it on the day following the day that contains the temporal parameter of the context. Obviously, it is impossible for a context to meet both requirements. Note that in (2a), where 
the thought of Doris is rendered as direct discourse, there are no such (seemingly) contradictory requirements: All deictic expressions (i.e., the pronoun as well as the tense markings and the temporal adverb morgen) are interpreted with respect to Doris's context, i.e., the situation in which she has the thought reported by the sentence. Likewise, in (2b), where Doris's thought is rendered as indirect discourse, there is no (seeming) inconsistency in the behavior of deictic expressions, since the deictic temporal adverb morgen (>tomorrow $<$ ) has been replaced by the non-deictic one am nächsten Tag (>the next day<), which is (indirectly) anaphorically related to the temporal location of the situation introduced by the previous sentence.

Restricting our attention to analyses that have been proposed by theoretical linguists for the purposes of this article, there are two strands of analysis that aim at capturing the inconsistent behavior of deictic expressions in FID. The first one builds on Doron (1991; see Rauh 1978, for a conceptually similar analysis couched in a generative syntactic framework) and has been further developed in technically quite different ways by Schlenker (2004), Sharvit (2008) and Eckardt (2014). The present exposition is mainly based on Eckardt (2014), who assumes that linguistic expressions can in principle not only be interpreted with respect to a single extralinguistic context $C$ (Kaplan, 1989), which corresponds to the utterance context in oral conversation and to the narrator's context in fictional discourse. Rather, it is possible to introduce a second context $c$, whose author is some prominent protagonist, whose temporal parameter is the reference time of the ongoing story and whose local parameter is the location of that protagonist at the reference time in the story world. Crucially, while pronouns and tenses are lexically specified to be interpreted with respect to $C$ exclusively, all other deictic expressions have to be interpreted with respect to $c$ whenever $c$ is introduced in addition to $C$. Additionally, the proposition denoted by a sentence that is interpreted with respect to both $C$ and $c$ is automatically interpreted as the content of a thought (or utterance) that the author of $c$ has (or makes) at the time of $c$. The second sentence in (2c) is thus interpreted as the content of a thought that Doris has at the time of her sighing, with morgen (>tomorrow $<$ ) referring to the day following the day that includes the temporal location of $c$, i.e., the time of Doris's sighing. The past tense, in contrast, is interpreted with respect to the narrator's context $C$. There are thus no contradictory temporal specifications, and the sentence receives a coherent interpretation.

Maier $(2015,2017)$ argues for a different analysis according to which FID is a special, highly conventionalized form of mixed quotation (see also Dirscherl/Pafel 2015): In his view, FID only differs from direct discourse in two respects. First, there are no quotation marks or any other kinds of typographical marking indicating quotation. Consequently, the reader has to accommodate a speech or thought act whose content is (partially) quoted. Second, certain parts of the quoted thought or utterance are unquoted - namely pronouns and verbal tense markings, which are accordingly interpreted with respect to the narrator's context. In Maier's account, the unquotation of pronouns and tenses in FID is a pragmatically motivated convention, however, and not the result of lexical specifications.

In cases such as $(2 \mathrm{c})$, where the preceding linguistic context makes only one protagonist available, the identification of an anchor for FID - i.e., a protagonist to whom the respective sentence or text segment can be ascribed as a thought or 
utterance - is trivial, of course. In Hinterwimmer (2019) and Hinterwimmer/Meuser (2019), however, it is shown that only protagonists that are either locally or globally maximally prominent are available as anchors for FID. This is in accordance with Himmelmann/Primus (2015), who define prominence as the property of an element to stick out from among a set of equals, which in turn, can be determined on the grounds of whether the element is available for anchoring relations. Locally maximally prominent protagonists are protagonists functioning as agents or experiencers of the eventuality introduced by the immediately preceding sentence. Globally maximally prominent protagonists, in contrast, are protagonists functioning as discourse topics of the entire text segment, i.e., they are the protagonists about whom the entire text segment is intuitively understood to convey information. As we will see in the following section, however, discourse topics are not automatically perspective takers. Rather, discourse topicality is a precondition for availability as perspective taker in the absence of local prominence.

Next to FID, there is another form of protagonists' perspective taking in narrative discourse which involves the representation of conscious perceptions rather than thoughts or utterances and has been dubbed Viewpoint Shifting (VS) in Hinterwimmer (2017) (see also Cohn 1978; Banfield 1982; and Fludernik 1993, for related discussion).

When Mary stepped out of the boat, the ground was shaking beneath her feet for a couple of seconds. (Hinterwimmer 2017, p. 291, ex. 14)

The main clause in (3) has two readings: On the first reading it simply reports an event that actually occurred (in the story) and was, for instance, caused by an earthquake. On its second reading, however, the main clause does not describe an actual event, but rather an internal sensation of Mary that was presumably caused by the boat trip, which has disturbed her sense of balance temporarily. The second reading of the main clause can be paraphrased as the ground seemed (to her) to be shaking beneath her feet for a couple of seconds. On this second reading, the main clause in (3) is a clear instance of VS. Similarly to instances of FID such as the second sentence in $(2 \mathrm{c})$, where there is no propositional attitude verb indicating that the respective sentence is to be interpreted as a thought of the protagonist, there is no verb such as seem in the case of (3), which would indicate that the clause is to be interpreted as an illusionary perception. In clear contrast to FID, however, which is only available at the root level (see Hinterwimmer 2017, for detailed discussion), the shift to Mary's perspective happens sentence-internally: The when-clause provides a neutral description from the narrator's perspective of an event which involves Mary as agent and thus makes her available as an anchor for VS, which happens in the main clause. While clearly describing a perception of Mary in a way that is compatible with her belief state at the time of the perception, it is rather implausible that the main clause is a rendition of an explicit thought of Mary.

In Hinterwimmer (2017), VS is analyzed along the following lines: A covert operator is inserted that takes the eventuality predicate denoted by the respective clause as its argument and turns it into a predicate describing an eventuality that is true in all of the worlds that are compatible with the belief state of some contextually provided prominent protagonist at the time immediately following a contextually 
provided perception. Both the protagonist and the predicate describing that perception are initially given in the form of free variables to be resolved on the basis of contextual information. The main clause in (3), where the individual variable is resolved to Mary and the free predicate variable is resolved to a sensation of Mary's sense of balance, therefore receives an interpretation that can be paraphrased as follows: There is a perceiving event $e$ whose experiencer is Mary and which is an internal sensation of her sense of balance and in all worlds that are compatible with Mary's belief state at the time of $e$ there is an event $e$ ' of the ground shaking beneath Mary's feet.

\section{German demonstratives marking perspective shifts}

In this section, we introduce a slightly modified version of Hinterwimmer's (2018) analysis of the use of demonstrative pronouns in the crime novel Auferstehung der Toten (literally, >Resurrection of the Dead<, translated as >Resurrection. The first Inspector Brenner novel $<$ ). Building on Hinterwimmer/Bosch (2017), Hinterwimmer (2018) shows that the use of demonstrative pronouns of the der/die/das series (dpronouns) in that novel in many instances serves to mark the narrator's perspective in all cases where the main protagonist of the novel, the private detective Simon Brenner, is at the same time the discourse topic of the respective text segment, he can only be referred to by a d-pronoun if the narrator is prominent as a perspective taker.

As already said in the introduction, German has two series of demonstrative pronouns in addition to personal pronouns - d-pronouns, which are used more often in the informal register, and dieser/dieseldieses pronouns, which are confined to the formal register (see Patil et al. 2020) and will not be discussed any further in this paper. There is a general consensus in the literature that d-pronouns have a strong tendency to avoid maximally prominent discourse referents as antecedents, where maximal prominence has been identified with subjecthood (Bosch et al. 2003, 2007) discourse or aboutness topicality (Bosch/Umbach 2006; Hinterwimmer 2015) and proto-agentivity (Schumacher et al. 2015; Schumacher et al. 2017). Based on contrasts like the one between the continuations of (4) in (4a) and (4b), however, Hinterwimmer/Bosch (2017) argue that d-pronouns are sensitive to perspectivetaking as well. Note that DPro stands for d-pronoun and PPro for personal pronoun.

Als Peter ${ }_{i}$ abends nach Hause kam, war die Wohnung wieder in einem fürchterlichen Zustand.

>When Peter $_{i}$ came home in the evening, the flat was in a terrible state again.<

(4) (a) $\left\{{ }^{*} D_{e r} / E r_{i}\right\}$ hatte doch gestern erst aufgeräumt.

$>$ But he $\left\{{ }^{*} \mathrm{DPro}_{\mathrm{i}} / \mathrm{PPro}_{\mathrm{i}}\right\}$ had just tidied up yesterday.<

(4) (b) $\left\{\right.$ Der $\left._{i} / E r_{i}\right\}$ kann sich einfach nicht gegen seinen Mitbewohner durchsetzen.

$>\mathrm{He}\left\{\mathrm{DPro}_{\mathrm{i}} / \mathrm{PPro}_{\mathrm{i}}\right\}$ is simply unable to stand his ground against his flatmate.< (Hinterwimmer/Bosch 2017, p. 117, ex. 17) 
In (4b), Peter can felicitously be picked up by a d-pronoun as well as by a personal pronoun, while in the case of (4a) only a personal pronoun is fully felicitous. This contrast is completely unexpected under the assumption that d-pronouns avoid antecedents functioning as subjects (Bosch et al. 2003; Bosch et al. 2007), discourse topics (Bosch/Umbach 2006) or proto-agents (Schumacher et al. 2015; Schumacher et al. 2017): The proper name Peter is the subject of the temporal adjunct clause contained in the opening sentence, Peter is the agent of the event introduced by that clause, and he presumably is the discourse topic of the entire text segment. He should therefore be unavailable as an antecedent for the d-pronoun not only in the case of (4a), but in the case of (4b), as well.

What sets (4b) apart from (4a) is that the sentence clearly expresses an evaluative comment that is made by the narrator. This is signaled by the content as well as by the switch from past tense to present tense, which brings about a break in narrative continuity. It is thus the narrator, not Peter, who is the perspective taker with respect to (4b). The continuation in (4a) in contrast, is most likely interpreted as a thought of Peter rendered in FID. This is signaled by the deictic temporal adverb yesterday, which is most likely interpreted not with respect to the narrator's, but rather with respect to Peter's context, i.e., as referring to the day preceding the day which contains the situation introduced by the opening sentence. Likewise, the speech act particle doch, which does not have a straightforward English translation, is most likely interpreted as expressing (very roughly) Peter's rather than the narrator's surprise that both the proposition denoted by (4b) and the proposition denoted by the preceding sentence are true. Concerning (4a), it is thus Peter rather than the narrator who serves as the perspective taker.

Based on these and related observations, Hinterwimmer/Bosch (2017) argue that d-pronouns are anti-logophoric pronouns - they avoid antecedents functioning as perspective takers with respect to the proposition denoted by the clause containing the respective d-pronoun. In order to account for the observation that in instances of neutral narration with two potential antecedents d-pronouns have a strong tendency to avoid the one functioning as discourse topic, Hinterwimmer/Bosch (2017) argue that discourse topics are perspective takers by default, i.e., in the absence of an involved narrator functioning as perspective taker.

In Hinterwimmer (2018) the analysis of Hinterwimmer/Bosch (2017) is applied to the crime novel Auferstehung der Toten (>Resurrection of the Dead $<$ ). The novel is written in a rather colloquial style, with the entire story being told by a highly involved narrator who permanently gives extremely subjective comments and evaluations. At the same time, the narrator never occurs as a protagonist and therefore remains entirely abstract, although he is prominent as a perspective taker. As shown in detail in Hinterwimmer (2018), a close look at the text segments and sentences in which the main protagonist, the private eye Simon Brenner, is referred to by a DPro, as opposed to those in which he can only be referred to by a PPro, reveals the following pattern: Whenever the narrator is prominent as a perspective taker, Brenner can be referred to by a d-pronoun. In cases where Brenner is the perspective taker as well as in cases of neutral narration, in contrast, Brenner can only be referred to by a personal pronoun. 
Consider first the text segment in (5), where Brenner is picked up by a d-pronoun three times and by a personal pronoun only once, in spite of clearly being the discourse topic and although he is constantly referred to by DPs functioning as subjects and agents or experiencers.

[1] Jetzt hat es sich zufällig ergeben, dass der Polizist Simon Brenner, Kriminalinspektor oder welchen Rang der gehabt hat, bei der Polizei gekündigt hat.

>Now, it came about rather accidentally that the policeman Simon Brenner, police inspector or whichever rank he $\mathrm{E}_{(\mathrm{DPro})}$ had, quit his job at the police department.<

[2] Jetzt muss man wissen, dass der 19 Jahre bei der Kripo gewesen ist, [...]. $>$ Now, you have to know that he $\overline{\mathrm{e}}_{(\mathrm{DPro})}$ worked at the criminal investigation department for 19 years, [...].<

[3] Aber er hat es nie richtig weit gebracht [...].

$>$ But he never got very far [...].<

[4] Das war aber nicht der eigentliche Grund für seine Kündigung, weil der nie besonders ehrgeizig gewesen ist.

$>$ But that was not the real reason for his dismissal, because he $\mathrm{D}_{(\mathrm{DPro})}$ was never particularly ambitious.<

[5] Mehr so ein ruhigerer Typ, [...].

$>$ More of a calm type of person [...].<

[6] Jetzt hat der aber vor drei Jahren einen neuen Chef gekriegt, [...]. (Haas 2005, p. 13)

$>$ But now he (DPro) $_{\text {got a new boss three years ago }[\ldots] .<(\text { Own translation })^{4}}$

Now, Brenner is clearly not a perspective taker with respect to (5). Rather, the narrator provides background information about Brenner's career and character and is thus prominent as a perspective taker. That Brenner can be referred to by a dpronoun in (5) is thus expected in Hinterwimmer/Bosch's (2017) account. It is important to keep in mind that personal pronouns are not subject to a restriction that is complementary to the one holding for d-pronouns. Consequently, it is not the case that the use of the personal pronoun in the third sentence shows that Brenner is the perspectival center with respect to the proposition denoted by the sentence. This is evidenced by the fact that it can easily be replaced by a d-pronoun without any noticeable change in acceptability or interpretation, as shown in (6).

[1] Jetzt hat es sich zufällig ergeben, dass der Polizist Simon Brenner, Kriminalinspektor oder welchen Rang der gehabt hat, bei der Polizei gekündigt hat.

>Now, it came about rather accidentally that the policeman Simon Brenner,

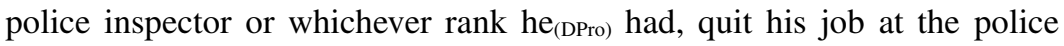
department.<

[2] Jetzt muss man wissen, dass der 19 Jahre bei der Kripo gewesen ist, [...].

\footnotetext{
${ }^{4}$ Here, we present a translation which is relatively close to the German original. In later sections, we will use published and therefore, less literal translations.
} 


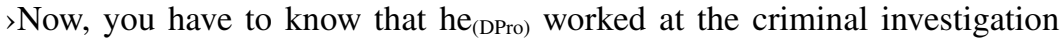
department for 19 years, [...].<

[3] Aber der hat es nie richtig weit gebracht [...].

$>$ But he ${ }_{(\text {DPro })}$ never got very far [...].<

[4] Das war aber nicht der eigentliche Grund für seine Kündigung, weil der nie besonders ehrgeizig gewesen ist.

$>$ But that was not the real reason for his dismissal, because he $\mathrm{E}_{(\mathrm{DPro})}$ was never particularly ambitious.<

[5] Mehr so ein ruhigerer Typ, [...].

$>$ More of a calm type of person [...].<

[6] Jetzt hat der aber vor drei Jahren einen neuen Chef gekriegt, [...]. (Haas 2005 , p. 13, modified)

$>$ But now he $\mathrm{e}_{(\mathrm{DPro})}$ got a new boss three years ago [...].<(Own translation)

Consider next the text segment in (7), in which Brenner is picked up by personal pronouns three times, and by a d-pronoun only once.

[1] Jetzt hat er natürlich wieder nicht gewusst, kommt es vom Rauchenaufhören, praktisch Entzug, weil der hat 40 am Tag geraucht.

>Now, again he didn't know, of course, is it because he stopped smoking, practically cold turkey, because he (DPro) used to smoke 40 a day.<

[2] Oder hat es mit der beruflichen Veränderung zu tun, dass er von den Sorgen Kopfweh kriegt, öfter als früher.

$>$ Or is it because of the change in his professional situation that he's getting a headache from his sorrows, more often than in the past.<

[3] Oder, dritte Möglichkeit, ist es das Klima in Zell, das er nicht verträgt, besonders jetzt, diese unnatürliche Hitze im September. (Haas 2005, p. 17)

$>$ Or, third option, is it the climate in Zell which he cannot stand, especially now, this unnatural heat in September.<(Own translation)

The embedded clause of the first sentence, as well as the second and third sentence, are most naturally interpreted as questions Brenner asks himself rather than as questions asked by the narrator. The embedded clause of the second sentence is thus an instance of indirect discourse, while the second and third sentence are instances of FID, and their content is interpreted as the content of an accommodated thinking event with Brenner as the experiencer. Brenner is thus the perspective taker in all three cases. Consequently, replacing the personal pronouns with d-pronouns leads to infelicity, as shown in (8), since the questions then have to be interpreted as questions asked by the narrator, which does not make much sense. The rightmost adjunct clause of the first sentence, in contrast, can easily be interpreted as a comment made by the narrator to give the reader some background information about Brenner. The narrator is thus locally prominent as a perspective taker with respect to that clause. This explains why Brenner can felicitously be referred to by a dpronoun in that clause.

[1] Jetzt hat der natürlich wieder nicht gewusst, kommt es vom Rauchenaufhören, praktisch Entzug, weil der hat 40 am Tag geraucht. 
>Now, again he (DPro) didn't know, of course, is it because he stopped smoking, practically cold turkey, because he (DPro) used to smoke 40 a day.<

[2] ??Oder hat es mit der beruflichen Veränderung zu tun, dass der von den Sorgen Kopfweh kriegt, öfter als früher.

>? Or is it because of the change in his professional situation that he $\mathrm{E}_{(\mathrm{DPro})}$ 's getting a headache from his sorrows, more often than in the past.<

[3] ?'Oder, dritte Möglichkeit, ist es das Klima in Zell, das der nicht verträgt,

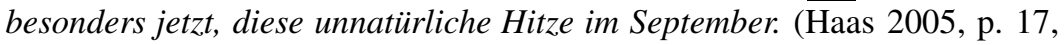
modified)

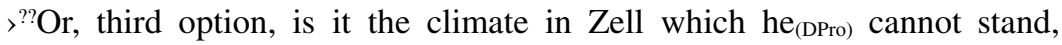
especially now, this unnatural heat in September.<(Own translation)

Consider finally the text segment in (9), in which Brenner is picked up by personal pronouns exclusively. As shown in (10), replacing the personal pronouns to d-pronouns leads to infelicity.

(9) [1] Und dann hat er noch einmal kehrtmachen müssen, weil er einen Gewinn gehabt hat, zehn Schilling, und die hat er sich gleich am Geldschalter geholt. >And then he had to go back, because he had a winning ticket, 10 Schillings, and he picked them up at the counter immediately.<

[2] Vor ihm ist so eine geschminkte Geschäftsfrau mit einem ganzen Stapel von Zahlscheinen gestanden.

$>$ In front of him stood one of those business women in full make-up with a whole stack of payment slips.<

[3] Jetzt hat er ein paar Minuten auf seinen Zehner warten müssen, und da ist ihm wieder die Melodie durch den Kopf gegangen, also ein richtiger Ohrwurm, [...]. (Haas 2005, p. 56)

>Now he had to wait for his 10 Schillings for a couple of minutes, and the melody went through his head again, a real catchy tune [...].< (Own translation)

(10) [1] ?'Und dann hat der noch einmal kehrtmachen müssen, weil der einen Gewinn gehabt hat, $\overline{z e h}$ Schilling, und die hat der sich gleich $\overline{\text { am }}$ Geldschalter geholt.

>And then he had to go back, because he had a winning ticket, 10 Schilling, and he picked them up at the counter immediately.<

[2] ??Vor dem ist so eine geschminkte Geschäftsfrau mit einem ganzen Stapel von Zahlscheinen gestanden.

$>$ In front of him stood one of those business women in full make-up with a whole stack of payment slips.<

[3] ?'Jetzt hat der ein paar Minuten auf seinen Zehner warten müssen, und da ist dem wieder die Melodie durch den Kopf gegangen, also ein richtiger Ohrwurm, [...]. (Haas 2005, p. 56, modified)

>Now he had to wait for his 10 Schillings for a couple of minutes, and the melody went through his head again, a real catchy tune [...].< (Own translation) 
The infelicity of (10) does not follow from the assumption that d-pronouns are anti-logophoric pronouns, since there are no clear indications that Brenner is the perspective taker in $(9) /(10)$. There is certainly no FID involved, since none of the sentences can naturally be interpreted as the content of an accommodated thinking event whose experiencer is Brenner, and there is also no indication of VS: In contrast to (3), it is extremely implausible that any of the reported events or states just describes a (potentially illusory) perception of Brenner. At the same time, although the entire story and therefore also the events and states in (9) are told by the narrator, there is no direct indication of the narrator's presence in the form of evaluations, comments, etc. The text segment in (9) is thus an instance of neutral narration. Following Hinterwimmer/Bosch (2017), Hinterwimmer (2018) assumes that Brenner, by virtue of being the discourse topic, is the perspective taker by default and can therefore not be picked up by a d-pronoun. This is problematic, however: As we have seen throughout this section, there are many instances where discourse topics are clearly not at the same time perspective takers. So, if discourse topics are only perspective takers by default, why should it not be possible to overwrite the default in the case of (10), in order to avoid violating the anti-logophoricity of d-pronouns?

In order to avoid this problem, we suggest the following modification: There is a general constraint preventing d-pronouns from picking up the most prominent discourse referent, where perspective takers are maximally prominent, followed by discourse topics. Consequently, in text segments such as $(5) /(6)$ with a perspectivally prominent narrator, d-pronouns are free to pick up discourse topics since there is a more prominent discourse referent, the narrator. In text segments such as $(7) /(8)$, in contrast, where the discourse topic is at the same time the perspective taker, it cannot be picked up by d-pronouns since it is maximally prominent in virtue of being the perspective taker. Finally, in neutrally narrated text segments such as $(9) /(10)$, where there simply is no perspective taker, discourse topics are maximally prominent as well and can therefore likewise not be picked up by d-pronouns.

\section{Temporal discourse structure (Becker/Egetenmeyer 2018)}

We follow the conception of temporal discourse structure introduced in Becker/ Egetenmeyer (2018). As the authors show, the temporal structure of narrative texts combines three structural levels, namely, (i) the relations between time points and temporal intervals, (ii) perspective time and (iii) foreground vs. background including a diversification according to story lines. Temporal ordering is relevant on all three levels and comes about in two ways which are always at play as they are located on orthogonal scales. On the one hand, there is a linear ordering and, on the other hand, there is also a hierarchical ordering. Beside unifying the mentioned three levels into one account, the strength of the approach is to determine the hierarchical relations at play in the realm of temporal discourse structure. They are modeled in terms of prominence, i.e., the property of an element (in this case, a time point) to stick out from among equal elements (cf. Himmelmann/Primus 2015; see also the section on free indirect discourse above). In Becker/Egetenmeyer (2018), Egetenmeyer (in press) and others, it is shown that basically, the prominence value 
of a time point or time span can be determined quantitatively on the grounds of the number of times which are anchored to it. Furthermore, a referentially precise and delimited time point may also be relatively prominent (cf. Egetenmeyer 2020).

The basic formalization of temporal relations in Becker/Egetenmeyer (2018) is oriented in discourse representation theory in the sense of Kamp and colleagues (cf. Kamp/Rohrer 1983; Kamp/Reyle 1993; Kamp et al. 2011; etc.). Thus, it focusses on location times and reference times (cf. Becker/Egetenmeyer 2018, especially p. $36 \mathrm{f}$.). The location time (abbreviated $l o c$ ) is the time when an eventuality $\gg$ is said to occur [...] [or] to hold « (cf. Kamp et al. 2011, p. 200). Adverbials may also introduce location times (cf. Kamp et al. 2011, p. 222). The reference time $(R)$, by contrast, is a more abstract concept. It determines narrative progression (cf. Kamp 2013, p. 116f., and Becker/Egetenmeyer 2018, p. 36f., with further explanations and references).

For the present contribution, the level of perspective is most important (see also Section 2; Coseriu 1976, p. 93-96, introduces relevant basic distinctions concerning perspective in the Romance tense system). The perspective time (PT) is a central ingredient of it. Basically, as Becker/Egetenmeyer (2018, p. 51) state, it »marks a time point from which a certain eventuality or a sequence of eventualities are seen «. In what concerns the realm of individuals, this requires a perspective taker. Formally, a perspective time is attributed to a reference time which is contextually available and needs to be relatively prominent (cf. Egetenmeyer 2020, with further references; a different formalization with respect to the perspective time is presented in de Saussure 2013, p. 53). As Becker/Egetenmeyer (2018, p. $51 \mathrm{f}$.) recapitulate, there are certain tense effects in Romance languages which are relevant for perspectivization. Most importantly, »[t]he pluperfect is a typical tense category which introduces a PT in discourse « (Becker/Egetenmeyer 2018, p. 51). As already indicated by Reichenbach ([1947] 1956, p. 290), the pluperfect makes reference to a pre-past event which is seen from the involved past reference time. Additionally, the imperfect, for instance in French, is often considered the prototypical tense of free indirect discourse (cf., e.g., Banfield 1982, p. 104, and many others, among them the refined analysis of Becker accepted). Furthermore, we already saw in Section 2 that Hinterwimmer (2018, p. 129f.) also mentions tense, and more specifically the present, as a possible indicator of perspective shift. Thus, there are strong interactions not only of individual reference with perspective, but also of tense and perspective. This may lead to a competition with the other and probably prototypical property of tenses (cf., e.g., Fleischman 1991, p. 26) to indicate temporal relations. We will not go into further detail here because the subject of tense as an indicator of perspectivization is addressed in depth in the following two sections.

\section{Romance tense marking perspective shift (Sthioul 2000)}

In the previous section, we mentioned potential correlations between tenses and perspective. However, the role of tenses for perspective shift needs further discussion. In order to implement them in our account, we adopt the analysis by Sthioul (2000). However, before going into the details, a few words concerning the French tense-

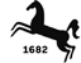


aspect system are in order. In what concerns literary texts making use of past tenses, French allows for a grammatical distinction which is not found in Germanic languages (cf. Dessì Schmid 2014 for a recent account which integrates grammatical and lexical properties into a coherent system). The two traditionally main past tense forms in literary narrations (cf. Weinrich 1982, p. 160-162) are also marked for aspect, namely, either imperfective (the French imparfait) or perfective (the French passé simple) (cf. Riegel et al. 2014, p. $536 \mathrm{ff}$.). ${ }^{5}$ In their temporal uses and due to the aspectual properties, the imparfait asserts only a sub-part of an eventuality in process, while the passé simple presents a situation globally (cf. Riegel et al. 2014, p. 522, 540 and p. 519, 537, respectively). However, both tense-aspect forms have acquired further functions, such as the modal uses of the imparfait (cf. Riegel et al. 2014, p. 545-547). Due to its diverse possible functions, Coseriu (1976, p. 129-169) compares the imperfective tense-aspect form with the present tense. According to him, the imperfect is the specified member of the opposition (the feature being [+inactual]) only with respect to the present ([-inactual]) but it is the unspecified member when it is opposed to other tense-aspect forms (cf. Coseriu 1976, p. 167-169). It is important to keep in mind that tense-aspect forms may adopt multiple functions and that they therefore need to be interpreted in the very context they occur in. ${ }^{6}$

This is one of the reasons for Sthioul $(2000$, p. $82 \mathrm{f}$.) to criticize the tradition of correlating certain French tenses directly with a non-narrator perspective. He refers to Damourette/Pichon $(1911-1935, \S 1709, \S 1806)$ who relate the French imperfect, pluperfect and conditional with the protagonist's perspective (cf. Sthioul 2000, p. 82). As indicated in Section 4, this might collide with grammatical tense's property of expressing temporal location. Sthioul also mentions Fleischman (1991) as supporting the hypothesis that in French, only tense-aspect forms involving the ending -ait (i.e., the ones listed above), may »marquer une focalisation interne, fonction qui ne saurait échoir au passé simple« (Sthioul 2000, p. 83, >mark an internal focalization, a function that could not be assigned to the simple past<). Sthioul (2000, p. $83 \mathrm{f}$.), by contrast, considers this too strongly simplified. He proposes a different account, which can be summed up as follows.

According to Sthioul (2000, p. 84), tense-aspect forms induce a basic expectancy in the hearer. They concern a restricted set of possible temporal relations, e.g., »antécédence, inclusion« (Sthioul 2000, p. 84, >precedence, inclusion $<$ ). If the expectancy is not met and the temporal interpretation would otherwise fail, a reinterpretation strategy is realized focusing on another possible meaning component of the tense-aspect form, namely, the one involving the contributed $\gg$ moment de conscience « (Sthioul 2000, p. 84, >moment of awareness $<$ ), an idiosyncratic term coined by de Saussure and Sthioul (see, e.g., de Saussure/Sthioul 1999), which is paralleled in Becker/Egetenmeyer (2018) by perspective time. The result of the reinterpretation is to »postuler que l'énoncé rend compte d'une pensée distincte de celle du locuteur

\footnotetext{
5 Not only in spoken but also in written language, the compound past (passé composé) has invaded the domain of the passé simple (cf. Riegel et al. 2014, p. 536, 539).

6 The contribution at hand only allows for rather brief notes. For an extensive study of the Romance tense, aspect and modality system and a discussion of different lines of research the reader is referred to Haßler (2016).
} 
au moment de l'énonciation « (Sthioul 2000, p. 84, >assume that the utterance reflects a thought distinct from that of the speaker at the time of speech<).

Therefore, according to Sthioul (2000, p. 80), there is only an indirect relation between tense-aspect forms and perspective shifts as it is the result of a relatively complex process. Following Genette ([1972] 1980), he defines a pragmatic process of perspectivization resolution which consists of four steps (cf. Sthioul 2000, p. 82, emphases are his):

1. Par défaut, un énoncé rend compte d'un état de choses (= énoncé non-focalisé).

2. Si une lecture comme état de choses n'est pas consistante ou si les hypothèses contextuelles favorisent une autre lecture, l'énoncé rend compte d'une pensée ou d'une sensation attribuée (= énoncé focalisé).

3. En ce cas, le destinataire cherche à récupérer dans l'univers dénoté un sujet de conscience adéquat (= énoncé en focalisation interne).

4. S'il n'y parvient pas, le destinataire construit une source de perception extérieure à l'univers dénoté (= énoncé en focalisation externe).

(>1. By default, an utterance refers to a situation (= unfocalized utterance).

2. If a reading as a situation is inconsistent or if contextual assumptions favor another reading, the utterance expresses an attributed thought or feeling (= focalized utterance).

3 . In this case, the recipient seeks to recover an adequate subject of consciousness in the denoted universe (= utterance with internal focalization).

4. If this is not possible, the recipient builds a source of perception outside the denoted universe (= utterance with external focalization). $<$ )

Thus, Sthioul (2000, p. 84) considers tenses indicators for sentence interpretation. ${ }^{7}$ What is special in his analysis as compared to the publications he criticizes (see above), is his treatment of the passé simple, which also makes way for his generalization that more than a few tenses may be involved in perspective marking. In accordance with the quotes we have seen above, Sthioul (2000, p. 89) states that the passé simple may also express perspective taking in certain contexts. One of his example pairs is (11) (Sthioul 2000, p. 90). It contains a stative verb in the second sentence whose tense-aspect form is manipulated.

(11) (a) Paul leva $a_{P S}$ les yeux. Un monstre effroyable se tenait Imp $_{\text {devant lui. (Sthioul }}$ 2000, p. 90)

$>$ Paul looked up. A terrible monster was standing in front of him.<

(11) (b) Paul leva $a_{P S}$ les yeux. Un monstre effroyable se tint $_{P S}$ devant lui. (Sthioul 2000, p. 90)

$>$ Paul looked up. A terrible monster stood before him.<

\footnotetext{
7 We agree with him in this and many other respects. Still, we have doubts in certain parts of his analysis. More concretely, he promotes a strong generalization concerning several uses of the imparfait (cf. Sthioul 2000 , p. $85 \mathrm{ff}$.). By contrast, we do not expect the imparfait use in sports reports to be determined by perspective (cf. Egetenmeyer in press).
} 
As Sthioul (2000, p. 90) states, the tense use in example (11a), where a passé simple (PS) is followed by an imparfait (Imp), is in accordance with what is to be expected. Namely, a state of affairs already holds at the reference time set by the eventuality of Paul looking up. Thus, there is no need for a shift in perspective. In (11b), by contrast, the PS (se tint, >stood $<$ ) operating on the stative verb yields a deviating interpretation as it cannot be interpreted as objectively global (cf. Sthioul 2000, p. 90), where the important boundary would be the left one, i.e., the beginning of the eventuality. A sequential interpretation such as $>$ Paul looked up and then the monster stood before him < is ruled out. Therefore, the PS has to express »la prise de conscience de cet état par le personnage« (Sthioul 2000, p. 90, >the becoming aware of the expressed state by the protagonist $<$ ). In the following section, we finally introduce our translation account for perspective marking.

\section{A translation account for perspective marking}

In Sections 3 and 5, we introduced the two main components of our account to compare the means of perspective marking in German and French. For German, we determined that d-pronouns, e.g., $\operatorname{der}(>\mathrm{he}<)$, indicate a perspective shift. For French, by contrast, we showed that unexpected tense use leads to a perspectivized interpretation. In the following, we introduce our staged account for the translations of der-marked perspectivized passages. By taking into account the mediation of perspective marking means from one language to the other, we are able to formulate the comparison between the two languages as a problem-solving process. Thereby, we can also consider otherwise excluded alternative conceptions. This is an important additional advantage to the fact that a translation - typically - yields two very much parallel texts in what concerns their content and, to a certain extent, how it is displayed, which is an important basis when comparing linguistic means.

The first step is a condition which needs to be fulfilled by the translator. The demonstrative pronoun needs to be recognized as a mark of perspectivization. There seem to be two main competing (»incorrect «) interpretations. One is a highlighting function sometimes attributed to the d-pronoun. The other one is an oppositive interpretation (see the example below). If the passage in question is interpreted correctly (or rather, not incorrectly), two options are available. The perspective shift may lack expression or it may be expressed or marked. There are different possibilities of expression, two of them may be considered overt or explicit. The first one is a lexical marking by means of adverbs or even longer strings. The second is a marking with tense. According to Hinterwimmer (2018, p. 129f.) a change from past to a present tense may be used. And as Becker/Egetenmeyer (2018, p. 50) show, the pluperfect is also associated with perspectivization. If there is no overt marking, there may still be a covert or pragmatic marking. This is the case for tense forms deviating from standard expectations (cf. Sthioul 2000). Finally, the last (theoretically) possible case is that there is no marking of perspective despite a correct interpretation. Of course, it then has the same value as the category »not recognized, without expression«. The relations are summed up in Table 1. 
Table 1 Recognition of perspective shifts and marking possibilities in French

\begin{tabular}{|c|c|c|c|c|c|c|}
\hline Perspective is & \multicolumn{2}{|c|}{... not recognized } & \multicolumn{3}{|c|}{... recognized/not misinterpreted } & \multirow[b]{2}{*}{$\begin{array}{l}\mathrm{No} / \\
\text { unclear }\end{array}$} \\
\hline Expression & Yes & No & Overt & Covert/pragmatic & & \\
\hline Possibilities & $\begin{array}{l}\text { Highlight } \\
\text { referent; } \\
\text { Oppositive } \\
\text { interpreta- } \\
\text { tion }\end{array}$ & - & $\begin{array}{l}\text { With lexical } \\
\text { means, e.g., } \\
\text { adverbs or } \\
\text { longer strings }\end{array}$ & $\begin{array}{l}\text { Tense: } \\
\text { Present tense (Hin- } \\
\text { terwimmer 2018); } \\
\text { Pluperfect (Becker/ } \\
\text { Egetenmeyer 2018) }\end{array}$ & $\begin{array}{l}\text { Tense } \\
\text { deviation } \\
\text { (Sthioul } \\
\text { 2000) }\end{array}$ & - \\
\hline
\end{tabular}

As the different means of marking perspective taking in French with tense are discussed in detail in Section 7, we will not present any examples here. It is important to note that when treating translations, a comparison cannot be done on a very restricted level of consideration such as the clause level. The reason is that translations may sometimes change the order of information units. Furthermore, they may also change the way of information packaging. This means that an indicator may shift its position from one clause to another and even across sentence boundaries. Therefore, we typically need to consider longer strings of text consisting of several sentences in sequence. We use sentence enumerations to be able to refer to different parts of the examples more readily. They may also render the matter visible when the respective indicators occur in different sentences in the source language and in the target language.

Before illustrating the cases where the perspective shift is recognized and reproduced in the target language (see in Section 7), we want to complete the picture by briefly showing a case of misinterpretation of the German d-pronoun as a marker of contrast. The following example is taken from our corpus (more specifically from Silentium!, see Section 7 for further information). The extract nicely shows the misinterpretation as it is made lexically explicit. The German original in fact presents a contrast in the second sentence of the example (Example (12), clause [2]). However, it is only a note expressed in the form of an apposition. Importantly, it is not the reason for the occurrence of the d-pronoun der (>he <). The translation, by contrast, emphasizes the information of the opposition by means of an adverbial clause (introduced by contrairement, >by contrast $<$ ).

(12) [1] Und Humboldt-Terrasse eben die Stelle, wo der Dr. Prader endlich einmal stehengeblieben ist.

Et c'est précisément sur la Humboldt-Terrasse que le Dr. Prader a fini par marquer un arrêt.

>And Humboldt's Terrace turned out to be the place where Dr. Prader finally stood still for a bit.<

[2] Der war drahtig wie ein Langläufer, fast ein bißchen das Gegenteil vom weichen Regens, und man hätte ihn eher für einen Bergführer gehalten als für einen Psychiater.

Contrairement à Regens qui était tout flasque, le Dr. Prader était grand et sec, comme un coureur de marathon, il avait davantage le physique d'un guide de haute montagne que d'un psychiatre. 
>He was wiry like a cross-country skier, almost a little like the opposite of the squishy dean, and you would've thought he was a mountaineer instead of a psychiatrist.<

[3] Da ist der um zehn Jahre ältere Brenner beim Hügelspazieren neben dem Salzburger Nurmi natürlich ein bißchen ins Schwitzen gekommen. (Haas 2009, p. 27)

Brenner, qui avait dix ans de plus que ce grand sportif, trainait un peu la patte au cours de la promenade, cela n'a rien d'étonnant. (Reygnier 2004, p. 31)

>Hiking up the hill had definitely made Brenner start sweating a little bit since he was ten years older than him and was trying to keep up with his quick Salzburg pace.<(Geisler 2013, p. 58)

The passage takes place during the walk up the hill of Brenner (the main protagonist) and Dr. Prader, a somehow involved informant. Dr. Prader is the local topic of [1] and [2]. The narrator muses on the physical constitution of Dr. Prader, which licenses the use of the d-pronoun. The comparison with the dean (Regens) is accidental or rather associative (cf. also the notes on how the narrator evaluates the narrated world in Hinterwimmer 2018, p. 123). Sentence [3] is a further indication that the passage indeed presents the external view of the narrator and not the one of Brenner himself. It is, thus, a case where the d-pronoun is licensed by a perspective shift. However, it is »misinterpreted « as contrastive by the translator. In the following section, we focus on cases where the translator recognizes the perspective shift and adopts linguistic means apt to express it in the target language.

\section{Perspective taking in two detective novels by Wolf Haas and their French translations}

We analyzed two detective novels by Wolf Haas to provide evidence for our translation account of perspective marking with tenses: Auferstehung der Toten (1996, $>$ Resurrection of the Dead<), translated into French as »Quitter Zell« (2007, >Leaving Zell $<$ ) and Silentium! (1999, >Silence $<)$, translated into French as »Silentium !« (2004). Both translations are by Marie Reygnier. To make the reading more accessible, we add English translations. ${ }^{8}$ However, they are not part of the analysis.

The novels are originally written in (Austrian) German and are expected to lead to interesting insights because of their unique style which has colloquial properties and a tendency towards a »train of thought « (see also Section 1). We started by collecting passages containing relevant d-pronouns in the German original. ${ }^{9}$ Like Hinterwimmer (2018), we focused on the main character of the story (overall topic). However, we also analyzed relevant local topics if they were referred to through-

\footnotetext{
8 Auferstehung der Toten was translated as >Resurrection. The first Inspector Brenner novel< by Annie Janusch (2014). Silentium! was partly translated by Paul Geisler (2013) as part of his MA thesis.

9 We collected the instances manually and may have missed some cases. Therefore, the numbers we present here are not used for statistical analyses.
} 
out various sentences in sequence. The reason is the reduced number of relevant d-pronouns in Silentium!. We then compared the passages they occurred in with the French translations and categorized the instances according to the classification system introduced in Section 6.

In Auferstehung der Toten/〉Quitter Zell<, we selected eleven passages containing d-pronouns referring to the main protagonist, Brenner, and two more referring to local topics. While in some cases specific grammatical constellations exclude the appearance of the phenomena of interest in the target language, namely, tenseaspect forms deviating from the expected ones, ${ }^{10}$ there are very nice examples which illustrate our point in a clear manner. We present three of them below. They are also quoted in Hinterwimmer (2018). Please note that we give translations sentence by sentence, despite the fact that we display longer text passages (see also Section 1). The sentences or relevant clauses are enumerated in square brackets. Importantly, it is only together that the enumerated sentences yield the entire text passage we discuss. The markers we are interested in do not have to occur in each of the quoted and translated sentences, but may sometimes only appear in one or two of them. Furthermore, as underlined in Section 6, the number of the sentence or clause where the marker in question appears may deviate in German and French. For instance, in the following example, the German d-pronoun occurs in clause [3], while the most important verb form in the French translation is to be found in clause [2]. Partly, this has to do with the fact that the translator chose to invert part of the given information.

(13) [1] Dazu mußt du wissen, an dem Tag, wo er bei der Polizei aufgehört hat, hat er aus einem gewissen Dings heraus auch mit dem Rauchen aufgehört. Und genau seit der Zeit hat er mindestens zweimal im Monat einen Migräneanfall, daß er kaum mehr aus seinen Tschechenaugen herausschauen kann.

Pour bien comprendre, tu dois savoir que, le jour où il avait démissionné, il avait aussi, pour une raison quelconque, décidé d'arrêter de fumer. Depuis ce jour-là, très précisément, il avait, au moins deux fois par mois, une migraine si atroce que sa vue se brouillait et que ses yeux de Tchèque lui refusaient tout service.

>About his head, you should know, on the day he quit the force, he also, out of some kind of, I don't know, quit smoking. And ever since that day, at least twice a month he gets a migraine that leaves him barely able to see out of those Czech eyes of his.<

[2] Jetzt hat er natürlich wieder nicht gewusst, kommt es vom Rauchenaufhören, praktisch Entzug,

Avant, il fumait jusqu'à deux paquets par jour.

$>$ Of course, he couldn't be sure: was it from quitting smoking - basically withdrawal,<

[3] weil der hat 40 am Tag geraucht.

10 It should be recalled that the investigated linguistic phenomena do not necessarily have to appear neither in German (see Section 3) nor in French (see Section 5) as has also been mentioned in Section 6. 
Évidemment, il n'aurait su dire si c'était lié à la privation de tabac, à quelque chose comme un phénomène de manque.

>because he smoked forty a day.<

[4] Oder hat es mit der beruflichen Veränderung zu tun, dass er von den Sorgen Kopfweh kriegt, öfter als früher.

Ou bien si les maux de tête plus fréquents étaient dus à des soucis divers ou à des changements dans sa vie professionnelle.

$>$ Or did it have to do with the career change, why he was getting headaches more often than he used to get, from the worrying.<

[5] Oder, dritte Möglichkeit, ist es das Klima in Zell, das er nicht verträgt, besonders jetzt, diese unnatürliche Hitze im September. (Haas 2015, p. 17; also quoted in Hinterwimmer 2018, p. $133 \mathrm{f}$.)

Ou bien encore, si c'était à cause du climat, car en ce mois de septembre, il faisait à Zell une chaleur tout à fait inhabituelle pour la saison. (Reygnier 2007, p. 23)

>r, third possibility, it was just the weather in Zell that didn't agree with him, especially now, this heat in September, just unnatural.< (Janusch 2014, p. 17)

Example (13) was already discussed in Section 3. It treats possible reasons for the frequent headaches of Brenner. For more context, we added two preceding sentences (see [1]). In what concerns the first relevant sentence of the German original ([2] and [3]), we see that the information is presented differently in the French translation. ${ }^{11}$ Somewhat simplified, we might state that the information is inverted. In German, sentence [2] displays the standard perspective of the book, namely, the one of Brenner (cf. Hinterwimmer 2018, p. 123). The causal clause, which features der (dpronoun $>$ he $<$ ) ([3]), by contrast, expresses the narrator perspective as Hinterwimmer (2018, p. 134) shows. This analysis may also be underlined by the classification, e.g., by Antomo/Steinbach (2010, p. $16 \mathrm{ff}$.), according to whom a verb-second weilclause like the one in the example can be classified as an epistemic explanation (term by Kempen/Harbusch 2016, who, however, opt for another classification). ${ }^{12}$

The French translation shows the following strong indicator of a non-protagonist perspectivization (see the French sentence under [2] which corresponds to [3] of the German original). The adverb avant (>before $<$ ) is associated with a backwardlooking temporal perspective. Therefore, in a past context as the one of the example (see [1]), a verb marked by the pluperfect (avait fumé, ’had smoked $<$ ) indicating pre-past would be expected. This is further substantiated as the verbs occurring in the following sentences are marked by the imparfait, and a pluperfect in [2] would clearly express prevailing temporal anteriority. Still, the verb in [2] is also marked by the imparfait (fumait, >used to smoke $<$ ). The expectation violation is resolved through the reading of the sentence as a meta-comment by the narrator, i.e., a perspective shift to the narrator, thus paralleling the German original.

11 Clause [4] is not a perfect match either. The translator adds des soucis divers (>diverse worries<).

12 We thank Klaus von Heusinger for pointing this out to us (p.c., $7^{\text {th }}$ January, 2019). 
The divergence between the two languages is related to a differing vantage point. The German text is oriented towards the speech-time, as indicated by the twofold use of the adverb jetzt ( $>$ now $<)$ (see [2] and [5]), the perfect tense in [2] and [3] and the present tense in [4] and [5]. A speech-time anchoring also seems to be expressed in the narrator's comment in [3], even though the reader may infer a past reference on the grounds of the lexically given opposition between Rauchenaufhören (>quitting smoking $<$ ) and hat geraucht (>smoked $<$ ). In contrast to the German original version, the French translation is centered around a past vantage point. The alternative explanations for Brenner's headaches ([3] to [5]) pertain to the main time line of the story which is given in the extended context and are coherently marked by the imparfait (si c'était lié, si ... étaient dus, si c'était à cause, il faisait). However, the adverb avant (>before $<$ ) sets the reference point somewhere before this narrated time at which the habit of smoking holds true. Thus, the eventualities of [3] to [5] do not share the reference time of [2], even though fumait (>smoked/used to smoke<) in [2] is also marked by the imparfait. This leads to the above-mentioned clash with expectations. ${ }^{13}$ The pre-past vantage point of fumait makes it clear that the content is not perspectivized from the protagonist's now but that we are dealing with a metacomment by the narrator, who moves freely along the time-line of narration.

In example (13) above, we saw the case where French indicated perspective taking by means of an imperfective tense-aspect form. In (14), by contrast, it is a passé simple form which triggers the perspectivized reading (cf. also Sthioul 2000, see Section 5). The passage describes the events of a time preceding the one of the main story line, where Brenner solved another case.

[1] Da ist der Brenner wieder der Richtige gewesen.

Dans l'affaire de Zell, Brenner fut vraiment l'homme de la situation.

$>$ So, once again, Brenner was the right one.<

[2] Wenn man den so gesehen hat in Zell, wäre man nicht leicht darauf gekommen, dass der ein Privatdetektiv war.

À le voir comme ça, à Zell, bien malin qui aurait pu dire qu'il était détective. >If you'd seen him looking the way he did in Zell, you wouldn't have guessed that he was a private detective.<

[3] Obwohl-der war kein Geheimdetektiv.

De toute façon, l'enquête n'avait rien de confidentiel.

$>$ Even though he was no undercover detective.<

[4] Hat es jedem gesagt, der es wissen wollte, dass er wegen der Liftgeschichte da ist. (Haas 2015, p. 15; also quoted in Hinterwimmer 2018, p. 132)

Brenner n'en faisait d'ailleurs pas mystère et quand on lui demandait pourquoi il était là, il répondait que c'était à cause du double crime des télésièges. (Reygnier 2007, p. 20f.)

$>$ Anybody who wanted to know, they got told - he was there on account of the lift scandal.<(Janusch 2014, p. 14)

\footnotetext{
13 The pre-past use of the imparfait is licensed by the expressed habituality concerning the smoking. This,
} however, does not prevent the temporal referential clash. 
According to Hinterwimmer (2018, p. 133), in (14), sentences [1], [2] and [3] express personal assessments concerning Brenner and his reception in the city of Zell as related by the narrator. The shift in perspective towards the narrator is marked by the use of the d-pronouns (den, >him<, and twice der, >he $<$ ) in [2] and [3]. The first reference to the protagonist with a full NP results from the necessity of disambiguation or, rather, the setting of a contrastive topic.

In French, the perspective taking by the narrator is marked with an unexpected tense use in the first sentence. The prepositional phrase dans l'affaire de Zell (>in the case of Zell $<$ ) is combined with a stative expression (être l'homme de la situation, >be the decisive person in the situation $<$ ). This may be classified as a typical expression for ground setting. In such a background sentence, an imparfait would be expected (cf. Weinrich 1982, p. $168 \mathrm{ff}$.) indicating that the situation is viewed from within (cf. Comrie 1976, p. 4). The perfective passé simple (fut, >was $<$ ), by contrast, seems to lead to an inconsistency as it presents the situation as a bounded whole. This is resolved when the tense use is understood as an indicator of the perspective shift (cf. Sthioul 2000). On these grounds, a secondary effect is perceived, namely, the distancing of the situation from the time currently under discussion. The distancing leads to a clear temporal cut with respect to the context of utterance. Its effect is the impression of an important divergence between the presentation of the protagonist then vs. at the narrated time. The narrator focusses on the protagonist as he was in better days, thereby underlining that he used to be in a different condition than he is in the current story line. This effect would not come about with the corresponding imparfait (était, >was $<$ ). ${ }^{14}$ Thus, we may deduce that it is clearly the narrator who controls (i) the arrangement of the events on the temporal axis and (ii) the perspective from which the events are seen.

As we have seen, not only can the imparfait indicate perspective shift in French, but so can the passé simple. A third possibility was already introduced in Section 4, the pluperfect. This is shown in example (15).

(15) [1] Seit über einer Stunde sitzt er schon an seinem Zimmertischchen, wie er auf einmal bemerkt, dass er noch keine Zeile geschrieben hat.

Cela faisait plus d'une heure qu'il était assis à la petite table. Soudain, il s'aperçut qu'il n'avait pas encore écrit une seule ligne.

>For over an hour he'd been sitting at that small table in his room, when all of the sudden he realized - he still hadn't written a line.<

[2] Weil er ist mit seinen Gedanken ja völlig woanders gewesen.

II faut dire qu'il avait l'esprit complètement ailleurs.

>Because in his thoughts, he was somewhere else completely.<

[3] Das war seine alte Krankheit, dass er sich nicht konzentrieren kann.

II ne parvenait pas à se concentrer, ce qui n'avait rien d'étonnant quand on le connaissait.

>That was his old malady, that he couldn't concentrate.<

\footnotetext{
14 Without further context, a pluperfect (avait été, >had been $<$ ) also seems to be possible temporally. However, it would not match with the preceding context.
} 
[4] Äußerlich hat der Brenner ja einen furchtbar ruhigen Eindruck gemacht. [...]

De l'extérieur, Brenner donnait l'impression d'être incroyablement calme. $[\ldots]$

>Outwardly, Brenner gave the impression of being horribly calm. [...]

[5] Und da hat man ihn schon gut kennen müssen, dass man gewusst hat, wie nervös der die ganze Zeit gewesen ist.

II fallait vraiment le connaitre pour voir à quel point il était énervé.

>And you'd have to know him pretty well in order to know how anxious he was all the time.<

[6] Und konzentrieren, sagen wir auf das Wesentliche, das ist überhaupt nicht dem seine Stärke gewesen. (Haas 2015, p. 23; also quoted in Hinterwimmer 2018, p. 136.)

Se concentrer, je veux dire se concentrer sur des choses qui en valaient la peine, n'avait jamais été son fort. (Reygnier 2007, p. 30f.)

>And focusing on the essentials, let's say, that wasn't his strong suit at all.< (Janusch 2014, p. 25f.)

The passage states that Brenner is having trouble concentrating. As the extended context shows, this holds at the asserted time of the main story line ([1] and [2]). However, it is also stated to be a general property of the protagonist ([3] to [6]). While the beginning of this ascription ([3]) is underspecified as to who contributes the statement, it then ([4] ff.) becomes more and more clear that the generalization is performed by the narrator (cf. Hinterwimmer 2018, p. 136ff.). This licenses the use of the d-pronoun der (>he <) in [5] and of dem seine (>his $<$ ) in [6]. The French translation seems to maintain a relatively neutral perspective in the descriptions even though an external perspective taker is implicit (e.g., in [3], quand on le connaissait, >when one knew him $<$ ). However, in [6], there is finally an explicit reference to the narrator (je veux dire, >I want to say<). The external perspective taking is also indicated by the perspectivizing tense use: In the German original, the sentence is intended to continue the general characterization of Brenner. Therefore, the compound past of the previous sentences is maintained. By contrast, the French translation does not continue with the imparfait of the preceding sentences but features a pluperfect form (n'avait jamais été, >had never been<) despite the change of temporal reference. As we saw in Section 4 (and 6), this is a strong and relatively explicit indicator of a perspectivization (cf. Becker/Egetenmeyer 2018, p. 51). Thus, the example presents a third type of correspondence of perspective marking in German and French. As we will see below, this kind of perspective marking may lead to very interesting constellations of temporal reference in French.

In German, the excerpt starts with the present tense, which particularly highlights the moment of becoming aware of his unsuccessful attempts to write a text. Once again, the French translation transposes the whole scene into the past tense, with the reference point being set by the passé simple form s'aperçut (>noticed<). Interestingly, the final comment of the narrator features the pluperfect (qui [...] n'avait jamais été son fort, > which had never been his strong point $<$ ). So the interval of evaluation does not include the speech time but is restricted to some right boundary 
in the past. The temporal distance excludes an anchoring of the proposition to the protagonist's now and points to the narrator who takes stock of a particular property of the protagonist relevant in a past time interval.

In Silentium!/ $>$ Silentium !<, we collected two cases of d-pronouns referring to the main protagonist, Brenner. Furthermore, we found 13 cases of d-pronouns referring to secondary characters. The examples may serve to complete the picture.

Above, we showed the possibility of reproducing a marked perspective with a pluperfect form in French. In >Silentium !<, there are several passages where the pluperfect is maintained across various sentences. In several of these passages, the German original, by contrast, does not feature pluperfect forms. The availability of a continuous use of the pluperfect is a particularity of French among the Romance languages (cf. Lhafi 2012). Still, as the following example shows, this may lead to an interesting interplay of perspective marking with a somewhat »mechanistic « use of the tenses where the reader has to keep track of which tenses are being used for which story line.

(16) [1] Weil daß der Präfekt Fitz gern Priester geworden wäre und nicht ganz freiwillig geheiratet hat, haben im Marianum schon ein bißchen die Spatzen von den Dächern gezwitschert.

II faut dire que le préfet du sport Fitz, qui aurait bien aimé devenir prêtre, ne s'était pas marié tout à fait de son plein gré. Au Marianum, ce secret n'en était plus un.

>Because the fact that Prefect Fitz had really wanted to become a priest and hadn't married entirely of his own free will was frequently discussed through the grapevines of the Marianum.<

[2] Paß auf, daß der nicht geweiht war, ist nur auf ein tragisches Unglück zurückgegangen.

Écoute bien : il n'avait pas pu être ordonné prêtre à cause d'un accident tragique.

>Listen up: the fact that he hadn't been ordained goes back to a tragic accident.<

[3] Der Präfekt Fitz war ja früher der eifrigste Priester-Student.

Avant cette histoire, le préfet Fitz était l'un des étudiants les plus fervents de sa promotion.

$>$ Once upon a time, Prefect Fitz had been the most diligent student destined for the priesthood.<

[4] Aber furchtbare Ironie des Schicksals, ausgerechnet sein Fleiß hat ihn aus der Bahn geworfen.

Mais la vie est parfois cruelle, et il avait justement été victime de cette ferveur.

>But the horrible irony of fate kicked in; it was exactly his diligence that really screwed him over.<

[5] Weil vor lauter Studieneifer hat er es einmal übersehen und eine ganze Woche keinen Sport gemacht. (Haas 2009, p. $28 \mathrm{f}$.)

Tout à ses études, il n'avait pas fait de sport pendant une semaine, ce qui lui avait été fatal. (Reygnier 2004, p. 33) 
$>$ Because one week he had completely devoted all of his time to his studies and didn't play any sports.<(Geisler 2013, p. 59)

In (16), we find background information about Prefect Fitz. As the further context also underlines, the evaluations are contributed by the narrator (and not by Brenner), therefore, the passage may be classified as perspectivized by the narrator. This licenses the use of $\operatorname{der}(>h e<$ ) in [2]. The unpleasant information about Prefect Fitz concerns his past, therefore, there is an underlying pre-past reference. However, in what concerns sentence [2], the German original features a preterit (war, $>$ was $<$ ) thus expressing a (resultant) state. And there are good arguments for it as it is precisely this state which motivates the following exposition. Nonetheless, the translator chooses a pluperfect form. Thereby, she clearly marks the eventuality as perspectivized. The German original continues with another preterit in [3] (war, $>$ was $<$ ) and then switches to the present perfect, i.e., the colloquial narrating tense in [4] (hat geworfen, >threw <) maintaining it in [5] (hat übersehen, >missed $<$, hat gemacht, $>$ did $<$ ).

In the French translation, the tense choice continues to be quite different. In [3], the translator introduces an extended location time which makes the perspective time even more salient than in the German original. The German früher roughly equals >earlier, in former times<, while the French translation relates the preceding location time explicitly to the moment when the problem of the prefect takes place (avant cette histoire, >before this episode $<$ ). Furthermore, the translator choses an imparfait (était, >was $<$ ), even though due to the adverbial expression a pluperfect would be expected. Again, this may be interpreted as a case of perspective marking in the sense of Sthioul (2000). In the following sentence [4], however, the translator does not continue with the imparfait which would be possible on the grounds of the salient location time of [3]. Rather, she opts for a more explicit temporal marking of the relative relations by means of a pluperfect (avait été, >had been<). As the explicitness is unexpected in the context of the choice of [3], we may classify this as a further form marking perspective. The two pluperfect forms in [5] (n'avait pas fait, >had not done <, avait été, >had been<) continue the flashback. In the light of [4], we may interpret it as the expected choice attributing a tense form to a story line.

As indicated, the temporal structure of the passage under examination is mostly composed of pluperfect and conditional perfect forms, which convey a specific temporal profile to the whole segment of discourse. The narrator chooses a vantage point in the past from which he looks back to the decisive turning point (namely »the tragic accident «) of the protagonist's life. This backward-looking perspective is linked both to a modal and to a temporal structure: The modal structure revolves around the turning point, which decides and excludes alternatives (qui aurait bien aimé devenir prêtre in [1] vs. il n'avait pas pu être ordonné prêtre in [2]). The past vantage point determines the temporal structure and separates the past episode of the »tragic accident «, including an explanation (in [4], il avait justement été victime de cette ferveur, and [5], il n'avait pas fait de sport [...] ce qui lui avait été fatal) and the ensuing consequences ([1], il ne s'était pas marié tout à fait de son plein gré), from the narrator's NOW and his present context of commenting the episode (indicated by the formula il faut dire que in [1] and the additional écoute bien in [2]). 
To sum it up, the tense choice in the above example is a very strong indicator of the function of tense in French to mark perspective. The intermingling with the primary function of tense as (relative) location time indicator may lead to tense switches even within passages which are in principle coherent in their temporal reference.

Finally, as the comparison has shown, German and French both indicate perspective taking. However, they do this in a very different manner, which results from the divergent language-specific means which they have at their disposal. As we saw, the German original exploits the existing wide range of NP forms. More specifically, it allows for d-pronouns (der, den, etc.) to refer to the main protagonist in the story (or the aboutness-topic of the respective passage) - an otherwise excluded possibility - when the narrator becomes more prominent at that point of the narration. By contrast, the French translator exploits the various past tenses in order to signal the narrator's distance from the content of his narration and the protagonist's perspective. The narrator monopolizes the narration by exploiting his sovereign control over the timeline along which he moves back and forth, such that his perspective dominates the protagonist's perspective.

We already mentioned above that when the French translation makes use of a diverging tense-aspect form, it may entail a shift in the localization of the perspective time. In an extreme case, the temporal localization of an eventuality or a sequence of eventualities may not be identical in the translation with respect to the original. This then leads to different anchoring relations. In the following section, we complement our analysis by focusing specifically on the problem of the diverging anchoring potential related to tense-aspect choice in FID.

\section{Discontinuous anchoring in FID content in the French translations of two classic German novels}

In the following, we shift our attention to the second perspectivizing phenomenon, free indirect discourse (see Section 2 for a delimitation from viewpoint shift). We compare two classic German novels with their respective French translations. The first one is Thomas Mann's Buddenbrooks. Verfall einer Familie, first published in 1901. It was translated into French by Geneviève Bianquis as >Les Buddenbrook. Le déclin d'une famille<(2015). The second one is Der Untertan (1918) by Heinrich Mann and its translation into French as >Le sujet de l'empereur<(1982) by Paul Budry. They reveal many parallels and differences. Again, we add English translations to allow for an easy reading, but they are not subject to analysis. ${ }^{15}$ Here, we want to focus on a minor point in terms of frequency, which however illustrates two important divergences between the two languages at once. In short, German has a preference in FID to use continuous anchoring while French easily allows for discontinuous anchoring and shifts in temporal perspective. This may be taken as an indication of a diverging role of temporal adverbials and the strong effect of

15 The novel by Thomas Mann was translated by Helen Tracy Lowe-Porter as »Buddenbrooks. The decline of a family« (1922). Heinrich Mann's novel was translated as »The patrioteer« by Ernest Boyd (1921). 
French tense-aspect choice. In French, perspective marking seems to rank conceptually higher than determining temporal relations, including the marking of a forwardlooking temporal perspective.

The first example we want to discuss is from Heinrich Mann's Der Untertan. It is especially convenient because of the very clear divergence in the translation of sentence [4].

(17) [1] Mit künstlicher Jovialität verabschiedete er Diederich, der Agnes' Hand übersah und linkisch den Hut zog.

Avec une jovialité affectée il congédia Didier, qui, oubliant de voir la main que lui tendait Agnès, lui fit un coup de chapeau maladroit.

$>$ With forced good humour he said good-bye to Diederich, who ignored Agnes's hand, and lifted his hat awkwardly.<

[2] Auf einmal, mit überraschender Geschicklichkeit und ehe Mahlmann begriff, was vorging, schwang er sich auf einen vorbeifahrenden Omnibus.

Et tout d'un coup, avec une agilité surprenante, avant même que Mahlmann eut compris ce qui arrivait, il s'élança sur un omnibus qui passait.

>Suddenly, with surprising agility, he sprang onto a passing bus, before Mahlmann could grasp what was happening, $<$

[3] Er war entkommen!

Évadé !

$>$ He had escaped.<

[4] Und jetzt fingen die Ferien an!

Et demain les vacances commençaient.

$>$ Now the holidays were beginning

[5] Er war alles los! (Mann 1918, p. 33)

Libre en fin ! (Budry 1982, p. 42)

>and he was free of everything.< (Boyd 1921, p. 22)

The German original and the French translation of sentence [4] are actually very different. World knowledge is necessary to determine that both sentences refer to the same situation: The day on which the action takes place is the last day of lectures. According to the German original, vacation starts right after the last obligation. By contrast, French is more »loyal « to the calendar and determines the day after the one of the last lecture as the beginning of the holidays. What is of most interest to us is that in what concerns temporal relations on the content level (in contrast to the level of the utterance as an event, cf. Egetenmeyer accepted), the FID in the German version displays continuous anchoring. The French, by contrast, changes the anchor time. This can be shown with the Figures 1 and 2, respectively.

Figure 1 gives details for the German version. As it shows, the FID content only stands in an indirect relation to the discourse level (see the two timelines of which the upper one is the one of the main discourse). Sentence [3] expresses the post-state $\left(s_{1}\right)$ of an underspecified eventuality (see $\left.R_{i}\right)$. The end of the post-state coincides with the event $\left(e_{2}\right)$ expressed in [4]. The location time of the event $\left(\operatorname{loc}\left(e_{2}\right)\right)$ introduces a new reference time $\left(R_{2}\right)$, which equals the protagonist's now (see the use of jetzt, $>$ now $<$ ). The state $\left(s_{3}\right)$ expressed in [5] includes the reference time $R_{2}$. 
Figure 1 Temporal structure of the FID in the German version (clauses [3]-[5])

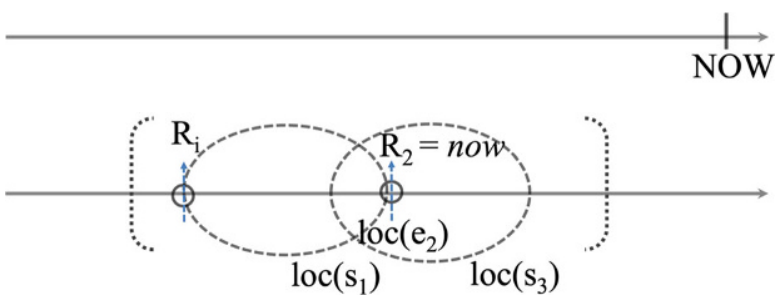

Figure 2 Temporal structure of the FID in the French version (clauses [3]-[5])

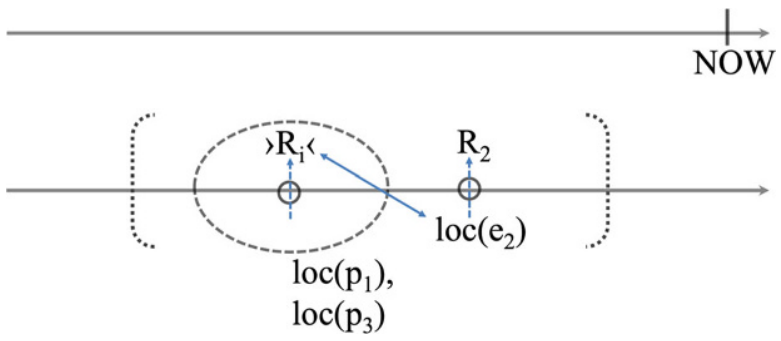

Figure 2, for the French version, indicates that there is a »virtual « reference time $\left(>R_{i}<\right)$ around which the content is ordered: The properties of having escaped $\left(p_{l}\right)^{16}$ (see [3]) and the one of being free at last $\left(p_{3}\right)$ (see [5]) are asserted for precisely that time. The elliptical nature of [3] (évadé instead of »il était évadé«) betrays the FID character of the passage. It is only in [4], however, that the reader is able to deduce that $>R_{i}$ < equals the protagonist's now. The localization is necessary for the anchoring of information concerning the next day in [4]. The use of demain ( >tomorrow $<$ ) parallels the German jetzt ( $>$ now $<$ ) in its property of underlining that it is the protagonist's perspective. Again, while the German original presents the content as temporally continuous, the French version shifts the reference time forward and then back again. Thus, in French, the virtual reference time $>R_{i}<$ needs to be relatively prominent.

As stated above, in Romance languages instances of FID tend to contain verbs marked by imperfective tense-aspect forms, which is a result of their double-anchoring properties (cf. Becker accepted). Temporally, the imperfect marks that the FID event (cf. Egetenmeyer accepted, for the term) is realized in the past with respect to the speech time (the narrator's $N O W$ ). Aspectually, the imperfect marks that the thought-content (i.e., the underlying proposition of the FID) is attached to a secondary source, the protagonist's now (cf. Becker accepted). This is also the case in the French example above. In this example, however, one might expect a conditional, i.e., a future in the past, due to the temporal reference we discussed above. Apparently, this is not strictly necessary. The imparfait use parallels a nonfree indirect speech event which, departing from an original speech event containing a present tense, might also yield a verb marked by the imparfait. Still, as FID is a strictly literary means, a less colloquial and more precise form may be taken to be preferable. Therefore, we may conclude concerning the example at hand that

16 The abbreviation $p$ here stands for the stage level property. 
the marking of the perspectivization (non-narrator's perspective) with the imparfait is more important to the author than a precisely determined temporal location (via a conditional).

The relations of the example above might partly be determined by a diverging conceptualization of the beginning of vacation in the two language communities. By contrast, this is excluded in the following example. This second example comes from Thomas Mann, Die Buddenbrooks.

(18) [1] Der Konsul ging, die Hände auf dem Rücken, umher und bewegte nervös die Schultern, denn das Gesicht, mit dem sie das Wort »dos« hervorbrachte, war gar zu unsäglich stolz.

Le consul marchait de long en large, les mains derrière le dos, et secouait nerveusement les épaules, car le visage avec lequel elle prononçait le mot latin dos était excessivement fier.

>The Consul walked up and down with his hands behind his back, his shoulders twitching nervously. Tony's face, as she uttered the word dos was too unutterably self-satisfied!<

[2] Er hatte keine Zeit.

II n' avait pas le temps.

$>$ He had no time.<

[3] Er war bei Gott überhäuft.

II était débordé de travail, par Dieu !

$>$ Heaven knew he had no time.<

[4] Sie sollte sich gedulden und sich gefälligst noch fünfzigmal besinnen!

Elle n'avait qu'à prendre patience, et il la priait de réfléchir encore cinquante fois.

$>$ Let her have patience, and wait, and bethink herself a hundred times.<

[5] Ihm stand jetzt zunächst, und zwar morgenden Tages, eine Fahrt nach Hamburg bevor: zu einer Konferenz, einer leidigen Unterredung mit Christian. (Mann 2011, chap. 6, part 11)

Le lendemain il partait pour Hambourg, il devait se rendre à une conférence, à une entrevue fâcheuse avec Christian. (Bianquis 2015, p. 397)

$>$ His nearest duty was a journey to Hamburg - indeed, he must go the very next day, for the purpose of a personal interview with Christian.<(LowePorter 1922, p. 386)

The FID in (18) is basically an expression of the nervousness of the protagonist. He begins with a characterization of his situation, thereby giving reasons why he does not have time to waste on the woman, Tony Buddenbrook (sentences [2] to [4]). This sets the background for the temporally interesting sentence [5], which, again, referentially diverges in German and French. Again, as indicated lexically, there is the divergence that the German original takes the protagonist's now as reference time, while the French translation introduces le lendemain (>the following day $<$ ) as reference time. Importantly, this adverbial, in contrast to demain (>tomorrow $<$ ) perspectivizes the situation from a vantage point in the past. In contrast to German morgen (and morgenden Tages, >the day of tomorrow<, as in the example), le lende- 
main is not a deictic but an anaphoric expression (see Riegel et al. 2007, p. 619) ${ }^{17}$ and therefore needs a reference point in order to be anchored. The point, which constitutes the anchor of the anaphoric expression le lendemain in this context, is the narrated time, equaling the protagonist's now, i.e., it is anchored to a reference time $R_{l}$ ', which is a slight update of the reference time introduced in sentence [1] $\left(R_{l}\right)$. The update comes about as part of the textual development within the FID event (cf. Egetenmeyer accepted). The adverbial expression introduces a forwardlooking perspective. The protagonist expresses his plans for the next day. As we see, it is the forward-looking value of the adverbial expression which allows the reader to localize the potential temporal reference of the denoted eventuality. Still, the temporal perspective is cancelled out by the second imperfective verb form (devait, $>$ had to $<) .{ }^{18}$ In this case, the reason for the leaving is given. The clause maintains an explanation relation in the sense of Asher/Lascarides (2003) to the preceding one. However, it is not part of the planning, even though the two verb forms share the same tense form and seem to be embedded under one adverbial expression. This flexibility indicates the strong value of the imparfait appearing in FID to indicate the perspective shift dominating other temporally relevant properties.

To conclude, we have seen cases where German FID content structure compellingly maintains a simple temporal structuring, either in the form of a sequence (see ex. 17, clauses [3]-[5]) or by using lexical elements (e.g., verbs and adverbials) which avoid any doubt that the reference time is simply maintained (see ex. 18). By contrast, French FID content showed a more liberal temporal structuring. As we have seen, temporal advancement followed by back shifts is possible (see ex. 17, clauses [3]-[5]) but a reference time may also be maintained despite a possible temporal shift due to a temporal adverbial expression. Thus, while in German the protagonist's now is always especially prominent, French also allows for a prominent narrated time, if we want to distinguish between the two types of times which generally coincide in FID.

The French flexibility is especially interesting when bearing in mind that the French tense-aspect system imposes certain restrictions on the possibilities of temporal ordering. A famous example is the tendency not to allow two events referred to with verbs marked by the passé simple to express an inverse ordering (cf., e.g., de Saussure 2000, p. $41 \mathrm{ff}$, for a discussion and see the examples under (19) which indicate that in English this is indeed possible).

(19) (a) \#Max tomba. Paul le poussa. (de Saussure 2000, p. 41, and others)

(19) (b) Max fell. Paul pushed him. (Cf., e.g., de Saussure 2000, p. 41)

Apparently, then, what counts most for French FID is that the perspective shift is to be marked by an imparfait or another imperfective tense form (conditional or pluperfect) (cf. Becker accepted). By contrast, the temporal localization and the temporal perspectivization are relatively less relevant for the tense-aspect choice. This is an interesting contrast to German, given the fact that French is, in certain

17 Due to this property, it may also easily occur in non-FID contexts.

18 The verbal description does not have a correspondence in German. 
contexts, quite restrictive when it comes to the relation between tense-aspect choice and temporal relations.

\section{Conclusion and open questions}

In the contribution at hand we compared German and French in perspectivized contexts, considering the phenomena of perspective taking and free indirect discourse (FID). We applied a translation account with German as the source and French as the target language, which allowed us to pinpoint different morpho-syntactic strategies in perspective marking and discourse structuring due to structural differences in the nominal and verbal domain of the two languages, with a richer determiner system in German and a more complex tense-aspect system in French. In addition to the innovative use of the translation account, our contribution also surpasses the limits of a (two-)sentence-based analysis as it rests specifically on the consideration of the level of discourse. In what concerns perspective taking, we analyzed data from two detective novels by Wolf Haas. For FID, we considered data from two classic German novels by Thomas Mann and Heinrich Mann. First, we showed that the two languages make use of different means to indicate a perspective shift. German with its diversified NP morphology opts for a d-pronoun (e.g., der, >he <) (cf. Hinterwimmer 2018). French, by contrast, is morphologically more diversified in the realm of tense-aspect and uses unexpected tense-aspect forms as indicators of perspective shift (cf. Sthioul 2000; Becker/Egetenmeyer 2018). Secondly, we focused on FID. In contrast to the variability of perspective marking in non-FID contexts, French has a strong preference for the imparfait in FID (cf. Becker accepted). As we showed, this allows for a more diversified temporal anchoring in French FID. More specifically, it allows for discontinuous anchoring. We hypothesize that this again results from the dual function of French tense-aspect forms, which may not only mark temporal relations, but also perspective shifts. If the choice of a form fulfils the function of perspective marking, the function of an exact temporal localization becomes less weighty. The flexibility in temporal anchoring thus appears as a consequence of the downgrading of the expression of the temporal relations as compared to perspective marking.

Concerning perspective taking, we may summarize the following. In German, we saw that a shift to the narrator's perspective licenses the use of a d-pronoun to refer to the otherwise most prominent protagonist (cf. Hinterwimmer 2018). In French, perspectivization is more strongly intermingled with temporality. The narrator sets vantage points in the past from which the respective episodes are »viewed « and temporally arranged. This technique of creating temporal distance from the protagonist's now marks the prevailing perspective, i.e., the perspective of the narrator. This functioning underlines his sovereign control over the time axis of the narration.

In FID passages, the perspective shifts to the protagonist who acts as a secondary source and anchor. German basically lacks a formal marking of this kind of shift. Still, like many other languages, it allows for the combination of, e.g., adverbials of future reference with past tenses (cf. Eckardt 2014; Hinterwimmer 2019; etc.). 
In French, the perspectivization is more clearly marked with an imparfait (cf., e.g., Banfield 1982), which in this case fulfills a double anchoring function (cf. Becker accepted). Due to its restrictions, German seems to have a tendency towards simple temporal structuring of FID passages. French, as we have seen, allows for more temporal referential diversity, including discontinuous anchoring, as long as the perspectivization itself is formally marked by the imparfait.

In addition to the fact that our account should be tested and substantiated further by increasing the amount of analyzed data, several questions are left for future discussion. Among them are the following two. (i) To furnish further support for our account, it would be helpful to also tackle the inverse question. Namely, under which circumstances are French passages displaying perspectivization indications translated into German using the d-pronoun as a perspective marker? The question is not easy to address. In an ad-hoc analysis of several French novels translated into German, we were not able to find any relevant uses of the d-pronoun in the German translations. (ii) We discussed different means of signaling perspective shift. A future analysis should focus more on how a certain perspective can be maintained.

Acknowledgements The research was funded by the Deutsche Forschungsgemeinschaft (DFG, German Research Foundation) as part of the Collaborative Research Center SFB 1252 Prominence in Language, Project-ID 281511265, which is gratefully acknowledged. The article represents joint work of the projects C02 und C05. We thank Robert Tegethoff for proof-reading and Barbara Zeyer and David Wick for practical assistance.

Funding Open Access funding enabled and organized by Projekt DEAL.

Open Access This article is licensed under a Creative Commons Attribution 4.0 International License, which permits use, sharing, adaptation, distribution and reproduction in any medium or format, as long as you give appropriate credit to the original author(s) and the source, provide a link to the Creative Commons licence, and indicate if changes were made. The images or other third party material in this article are included in the article's Creative Commons licence, unless indicated otherwise in a credit line to the material. If material is not included in the article's Creative Commons licence and your intended use is not permitted by statutory regulation or exceeds the permitted use, you will need to obtain permission directly from the copyright holder. To view a copy of this licence, visit http://creativecommons.org/licenses/by/4. $0 \%$.

\section{Corpus and Literature}

\section{Corpus}

Friebel, Gisela S. (2018): Maxi bringt ein Dorf in Rage. München: Cassiopeiapress.

Haas, Wolf (2004): Silentium !, translated by Marie Reygnier. Paris: Éditions Payot \& Rivages. (= Reygnier 2004)

Haas, Wolf (2007): Quitter Zell, translated by Marie Reygnier, Paris: Éditions Payot \& Rivages. (= Reygnier 2007)

Haas, Wolf ([1999] $\left.{ }^{20} 2009\right)$ : Silentium! Reinbeck bei Hamburg: Rowohlt Taschenbuch Verlag.

Haas, Wolf (2013): Silentium!, partly translated by Paul Geisler as part of his Master thesis (Geisler 2013, p. 37-66). The translated chapters are chapter one and chapter two. (= Geisler 2013)

Haas, Wolf (2014): Resurrection. The first Inspector Brenner novel, translated by Annie Janusch. Brooklyn, NY: Melville House Publ. (= Janusch 2014)

Haas, Wolf ([1997] ${ }^{25}$ 2015): Auferstehung der Toten. Reinbeck bei Hamburg: Rowohlt Taschenbuch Verlag.

Mann, Heinrich (1918): Der Untertan. Leipzig/Wien: Kurt Wolff Verlag.

Mann, Heinrich (1921): The patrioteer, translated by Ernest Boyd. New York: Harcourt, Brace and Company. (= Boyd 1921) 
Mann, Heinrich (1982): Le sujet de l'empereur, translated by Paul Budry, preface by J. Jourdheuil. Paris: Les presses d'aujourd'hui. (= Budry 1982)

Mann, Thomas (1922): Buddenbrooks. The decline of a family, translated by Helen Tracy Lowe-Porter. London: Martin Secker Ltd. (= Lowe-Porter 1922)

Mann, Thomas ([1901] 2011): Buddenbrooks. Verfall einer Familie. Projekt Gutenberg. In: https://archive. org/stream/buddenbrooksverf34811gut/pg34811.txt (12.12.2018).

Mann, Thomas ( $\left.{ }^{12} 2015\right):$ Les Buddenbrook. Le déclin d'une famille, translated by Geneviève Bianquis. Paris: Librairie Arthème Fayard. (= Bianquis 2015)

\section{References}

Antomo, Mailin/Steinbach, Markus (2010): Desintegration und Interpretation: Weil-V2-Sätze an der Schnittstelle zwischen Syntax, Semantik und Pragmatik. In: Zeitschrift für Sprachwissenschaft 29 (1), p. 1-37. https://doi.org/10.1515/zfsw.2010.001.

Asher, Nicholas/Lascarides, Alexander (2003): Logics of conversation. Cambridge et al.: Cambridge University Press.

Banfield, Ann (1982): Unspeakable sentences: Narration and representation in the language of fiction. Boston: Routledge \& Paul.

Becker, Martin/Egetenmeyer, Jakob (2018): A prominence-based account of temporal discourse structure. In: Lingua 214, p. 28-58. https://doi.org/10.1016/j.lingua.2018.08.002.

Becker, Martin (accepted): Free indirect discourse, quotative readings and the Romance imperfect. To appear in: Italian Journal of Linguistics.

Bosch, Peter/Umbach, Carla (2006): Reference Determination for Demonstrative Pronouns. In: Dagmar Bittner/Natalia Gagrina (Eds.): Proceedings of the conference on intersentential pronominal reference in child and adult language. Berlin: Zentrum für Allgemeine Sprachwissenschaft, p. 39-51.

Bosch, Peter/Katz, Graham/Umbach, Carla/Cummins, Philip/Gutbrod, Boris/Zhao, Yufan/Park, Kyoungho/Rozario, Tom Antony (2003): Preference and Reference: Analysing Demonstrative Pronouns in German. Poster at EuroCogsci 2003.

Bosch, Peter/Katz, Graham/Umbach, Carla (2007): The non-subject bias of German demonstrative pronouns. In: Monika Schwarz-Friesel/Manfred Consten/Mareile Knees (Eds.): Anaphors in text: Cognitive, formal and applied approaches to anaphoric reference. Amsterdam/Philadelphia: John Benjamins, p. 145-164.

Cohn, Dorrit (1978): Transparent minds. Narrative modes for presenting consciousness in fiction. Princeton, N.J.: Princeton University Press.

Comrie, Bernard (1976): Aspect. An introduction to the study of verbal aspect and related problems. Cambridge: Cambridge University Press.

Coseriu, Eugenio. (1976): Das romanische Verbalsystem. Tübingen: TBL-Verlag Gunter Narr.

Damourette, Jacques/Pichon, Édouard (1911-1936): Des mots à la pensée. Essai de grammaire de la langue française. Tome V: Verbe (fin). Auxiliaires, temps, modes, voix. Paris: D’Artrey.

De Mello, George (1992): El artículo definido con nombre propio de persona en el español hablado culto contemporáneo. In: Studia Neophilologica 64 (2), p. 221-234. https://doi.org/10.1080/ 00393279208588100.

Dessì Schmid, Sarah. (2014): Aspektualität. Ein onomasiologisches Modell am Beispiel der romanischen Sprachen. Berlin/Boston: de Gruyter.

Dirscherl, Fabian/Pafel, Jürgen (2015): Die vier Arten der Rede- und Gedankendarstellung. Zwischen Zitieren und Referieren. Tübingen: Buske (Linguistische Berichte 241).

Doron, Edit (1991): Point of view as a factor of content. In: Steven K. Moore/Adam Z. Wyner (Eds.): Proceedings of the 1st semantics and linguistic theory conference. Linguistic Society of America, p. 51-64.

Eckardt, Regine (2014): The semantics of free indirect discourse. How texts allow us to mind-read and eavesdrop. Leiden/Boston: Brill.

Egetenmeyer, Jakob. (Accepted): Temporal relations of free indirect discourse events. To appear in: Linguistics 59(4). https://doi.org/10.1515/ling-2021-0085

Egetenmeyer, Jakob (2020): The prominence value of the temporal anchor of free indirect discourse: A comparison with the perspectival center. In: Discours 27, p. 3-40. https://doi.org/10.4000/discours. 11101 
Egetenmeyer, Jakob (In press): Time updating uses of the French imparfait extending across genres. To appear in: Laura Baranzini/Louis de Saussure (Eds.): Aspects of tenses, modality, and evidentiality. Leiden/Boston: Brill Rodopi (Cahiers Chronos 31).

Fabricius-Hansen, Cathrine (2002): Nicht-direktes Referat im Deutschen - Typologie und Abgrenzungsprobleme. In: Cathrine Fabricius-Hansen/Oddleif Leirbukt/Ole Letnes (Eds.): Modus, Modalverben, Modalpartikel. Trier: Wissenschaftlicher Verlag Trier, p. 7-29.

Fleischman, Suzanne (1991): Verb tense and point of view in narrative. In: Suzanne Fleischman/Linda R. Waugh (Eds.): Discourse-pragmatics and the verb. The evidence from Romance. London/New York: Routledge, p. 26-54.

Fludernik, Monika (1993): Second person fiction: Narrative You as addressee and/or protagonist. In: Arbeiten aus Anglistik und Amerikanistik 18 (2), p. 217-247.

Fludernik, Monika (1996): Linguistic signals and interpretative strategies: Linguistic models in performance, with special reference to free indirect discourse. In: Language and Literature 5 (2), p. 93-113.

Geisler, Paul (2013): A translation study of Silentium! by Wolf Haas. Master thesis, Arizona State University. In: http://hdl.handle.net/2286/R.A.110248 (13.05.2019).

Genette, Gérard ([1972] 1980): Narrative discourse. An Essay in method. Ithaca, New York: Cornell University Press.

Hamburger, Käte (1968): Die Logik der Dichtung. Stuttgart: Ernst Klett.

Harweg, Roland (1972): Die reduzierte Rede. In: Linguistics 80, p. 44-55.

Haßler, Gerda (2016): Temporalität, Aspektualität und Modalität in romanischen Sprachen. Berlin/Boston: de Gruyter.

Himmelmann, Nikolaus/Primus, Beatrice (2015): Prominence beyond prosody - a first approximation. In: Amadeo de Dominicis (Ed.): pS-prominenceS: Prominences in linguistics. Proceedings of the international conference. Viterbo; Disucom Press, p. 38-58.

Hinterwimmer, Stefan (2015): A unified account of the properties of German demonstrative pronouns. In: Pritty Patel-Grosz/Patrick G. Grosz/Igor Yanovish (Eds.): The Proceedings of the workshop on pronominal semantics at NELS 40. Amherst, MA: GLSA Publications, p. 61-107.

Hinterwimmer, Stefan (2017): Two kinds of perspective taking in narrative texts. In: Dan Burgdorf/Jacob Collard/Sireemas Maspong/Brynhildur Stefánsdóttir (Eds.): Proceedings of SALT 27. Linguistic Society of America, p. 282-301.

Hinterwimmer, Stefan (2018): Der Brenner und die Perspektive: Zum Gebrauch von Demonstrativpronomen in den Brenner-Romanen von Wolf Haas. In: Metin Genç/Christof Hamann (Eds.): Kriminographien. Formenspiele und Medialität kriminalliterarischer Schreibweisen. Würzburg: Königshausen \& Neumann, p. 123-142.

Hinterwimmer, Stefan (2019): Prominent protagonists. In: Journal of Pragmatics 154, p. 79-91. https:// doi.org/10.1016/j.pragma.2017.12.003.

Hinterwimmer, Stefan/Bosch, Peter (2017): Demonstrative pronouns and propositional attitudes. In: Pritty Patel-Grosz/Patrick Georg Grosz/Sarah Zobel (Eds.): Pronouns in embedded context at the syntaxsemantics interface. Dordrecht: Springer, p. 105-144.

Hinterwimmer, Stefan/Meuser, Sarah (2019): Erlebte Rede und Protagonistenprominenz. In: Stefan Engelberg/Christian Fortmann/Irene Rapp (Eds.): Rede- und Gedankenwiedergabe in narrativen Strukturen - Ambiguitäten und Varianz. Special issue of Linguistische Berichte, p. 177-200.

Kamp, Hans (2013): Deixis in discourse. Reichenbach on temporal reference. In: Klaus von Heusinger/ Alice ter Meulen (Eds.): Meaning and the dynamics of interpretation. Leiden: Brill, p. 105-159.

Kamp, Hans/Reyle, Uwe (1993): From discourse to logic. Introduction to modeltheoretic semantics of natural language, formal logic and discourse representation theory, Pt. 2. Dordrecht et al.: Kluwer Academic Publishers.

Kamp, Hans/Rohrer, Christian (1983): Tense in texts. In: Rainer Bäuerle/Christoph Schwarze/Arnim von Stechow (Eds.): Meaning, use, and interpretation of language. Berlin/New York: de Gruyter, p. 250-269.

Kamp, Hans/van Genabith, Josef/Reyle, Uwe (2011): Discourse Representation Theory. In: Doy Gabbay/Franz Guenthner (Eds.): Handbook of philosophical logic, 2nd edn., vol. 15. Dordrecht et al.: Springer, p. 125-394.

Kaplan, David (1989): Demonstratives. In: Joseph Almog/John Perry/Howard Wettstein (Eds.): Themes from Kaplan. Oxford: Oxford University Press, p. 565-614.

Kempen, Gerard/Harbusch, Karin (2016): Verb-second word order after German weil >because <: Psycholinguistic theory from corpus-linguistic data. In: Glossa: A Journal of General Linguistics 1 (1), 3, p. 1-32. https://doi.org/10.5334/gjgl.46. 
Koch, Peter/Oesterreicher, Wulf ( $\left.{ }^{2} 2011\right)$ : Gesprochene Sprache in der Romania: Französisch, Italienisch, Spanisch. Berlin/New York: de Gruyter (Romanistische Arbeitshefte 31).

Lhafi, Sandra Christine (2012): Zum Plusquamperfekt im Französischen und Spanischen. Kontrastive Untersuchung aus textlinguistischer Perspektive. Frankfurt a.M. et al.: Peter Lang.

Maier, Emar (2015): Quotation and unquotation in free indirect discourse. In: Mind and Language 30 (3), p. 345-373.

Maier, Emar (2017): The pragmatics of attraction: explaining unquotation in direct and free indirect discourse. In: Paul Saka/Michael Johnson (Eds.): The semantics and pragmatics of quotation. Berlin: Springer (Perspectives in Pragmatics, Philosophy and Psychology 15), p. 259-280. https://doi.org/ 10.1007/978-3-319-68747-6_9.

Patil, Umesh/Bosch, Peter/Hinterwimmer, Stefan (2020): Constraints on German diese demonstratives: language formality and subject-avoidance. In: Glossa: A Journal of General Linguistics 5 (1), 14, p. 1-22. https://doi.org/10.5334/gjgl.962.

Plank, Frans (1986): Über den Personenwechsel und den anderer deiktischer Kategorien in der wiedergegebenen Rede. In: Zeitschrift für Germanistische Linguistik 13 (3), p. 284-308.

Rauh, Gisa (1978): Linguistische Beschreibung deiktischer Komplexität in narrativen Texten. Tübingen: Narr.

Reichenbach, Hans ([1947] ${ }^{5}$ 1956): Elements of symbolic logic. New York et al.: Macmillan.

Riegel, Martin/Pellat, Jean-Christophe/Riuol, René ( $\left.{ }^{4} 2007\right)$ : Grammaire méthodique du français. Paris: Presses Universitaires de France.

Riegel, Martin/Pellat, Jean-Christophe/Riuol, René (52014): Grammaire méthodique du français. Paris: Presses Universitaires de France.

Roncador, Manfred von (1988): Zwischen direkter und indirekter Rede. Nichtwörtliche direkte Rede, erlebte Rede, logophorische Konstruktionen und Verwandtes. Berlin/New York: de Gruyter (Linguistische Arbeiten 192).

de Saussure, Louis (2000): Quand le temps ne progresse pas avec le passé simple. In: Anne Carlier/Véronique Lagae/Céline Benninger (Eds.): Passé et parfait. Amsterdam/Atlanta: Rodopi (Cahiers Chronos 6), p. 37-48.

de Saussure, Louis. (2013): Perspectival interpretations of tenses. In: Katarzyna Jaszczolt/Louis de Saussure (Eds.): Time: Language, cognition and reality. Oxford: Oxford University Press, p. 46-69.

de Saussure, Louis/Sthioul, Bertrand (1999): L'imparfait narratif: point de vue (et images du monde). In: Cahiers de praxématique 32, p. 167-188.

Schlenker, Philippe (2004): Context of thought and context of utterance: a note on free indirect discourse and the historical present. In: Mind and Language 3, p. 279-304.

Schumacher, Petra/Backhaus, Jana/Dangl, Manuel (2015): Backward- and forward-looking potential of anaphors. In: Frontiers in Psychology 6, p. 17-46.

Schumacher, Petra/Roberts, Leah/Järvikivi, Juhani (2017): Agentivity drives real-time pronoun resolution: Evidence from German »er« and »der«. In: Lingua 185, p. 25-41.

Sharvit, Yael (2008): The puzzle of free indirect discourse. In: Linguistics and Philosophy 313, p. 353-395.

Stanzel, Franz (1979): Theorie des Erzählens. Göttingen: Vandenhoeck \& Ruprecht.

Sthioul, Bertrand (2000): Passé simple, imparfait et sujet de conscience. In: Anne Carlier/Véronique Lagae/Céline Benninger (Eds.): Passé et parfait. Amsterdam/Atlanta: Rodopi (Cahiers Chronos 6), p. 79-93.

Weinrich, Harald (1982): Textgrammatik der französischen Sprache. Stuttgart: Klett. 